PONTIFÍCIA UNIVERSIDADE CATÓLICA DO RIO DE JANEIRO

\title{
Plano de ação para uma empresa de serviços no ramo de consultoria
}

\author{
Eduardo de Castro Seabra
}

Trabalho de Conclusão de Curso

Centro de CiênCIAS SociaIs - CCS

DEPARTAMENTO dE AdMINISTRAÇÃO

Graduação em Administração de Empresas 
Eduardo de Castro Seabra

\section{Plano de ação para uma empresa de serviços no ramo de consultoria}

Trabalho de Conclusão de Curso

Trabalho de Conclusão de Curso, apresentado ao programa de graduação em Administração da PUC-Rio como requisito parcial para a obtenção do título de graduação em Administração.

Orientadora: Vivian Steinhäuser

Rio de Janeiro, 20 de junho de 2020. 


\section{Agradecimentos}

Dedico esse trabalho à minha família, que sempre me apoiou e me deu todos os recursos para chegar até aqui.

Agradeço também à minha orientadora Vivian Steinhäuser pelo apoio e incentivo para superar os desafios deste trabalho.

E por fim, um agradecimento especial à empresa GSeabra e aos seus colaboradores pela participação nas entrevistas e por disponibilizarem os materiais necessários à realização deste estudo. 


\title{
Resumo
}

Seabra, Eduardo. Plano de Ação para uma empresa de serviços no ramo de consultoria. Rio de Janeiro, 2020. 71 páginas do Trabalho de Conclusão de Curso Departamento de Administração. Pontifícia Universidade Católica do Rio de Janeiro.

O presente estudo tem como objetivo efetuar um plano de ação a partir do mix de serviços que compõem os 7P's em uma empresa de serviços do ramo de consultoria e perícias na área de engenharia. Para isso foram realizadas pesquisas de campo e de observação de cunho qualitativo com os colaboradores e clientes da empresa para analisar o seu posicionamento em relação a produto, praça, preço, promoção, processo, pessoas e ambiente físico. A partir dos resultados obtidos foi elaborada uma proposta de melhorias analisando os 7 P's.

Palavras-chave: marketing de serviços, consultoria, 7 P's, engenharia

\begin{abstract}
Seabra, Eduardo. Action Plan for a consulting services company. Rio de Janeiro, 2020. 71 pages of the Course Conclusion Paper - Administration Department. Pontifical Catholic University of Rio de Janeiro.

The present study aims to carry out an action plan based on the mix of services that make up the 7P's in a consulting and expertise service company in the engineering area. For this, field and qualitative observation surveys were carried out with the company's employees and customers to analyze their position in relation to product, place, price, promotion, process, people and physical environment. Based on the results obtained, an improvement proposal was elaborated by analyzing the 7 P's.
\end{abstract}

Keyword: service marketing, consulting, 7 P's, engineering 


\section{Sumário}

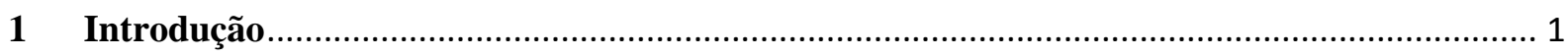

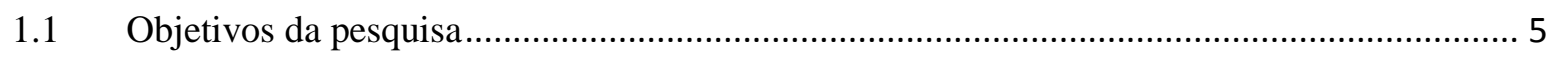

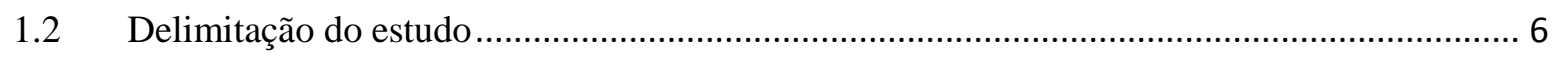

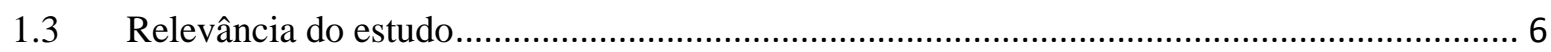

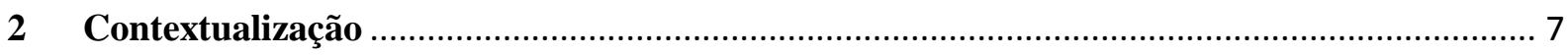

2.1 A ascensão do Marketing de Serviços........................................................................................ 7

$2.2 \quad$ Mercado de Consultoria no Brasil........................................................................................ 9

2.2.1 Segmento de Normas Regulamentadoras do Brasil .................................................... 11

3 Diagnóstico da Situação Problema e Oportunidades .......................................................... 12

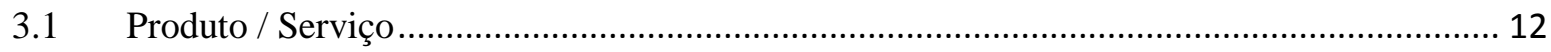

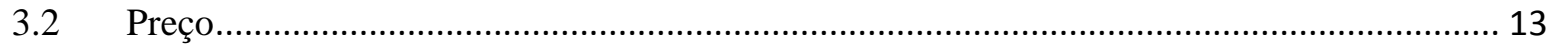

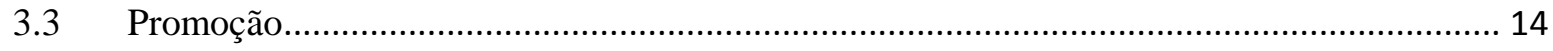

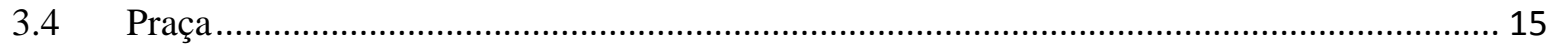

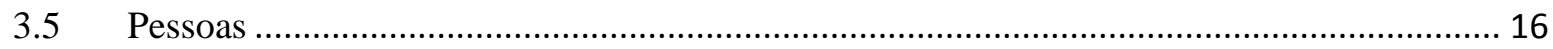

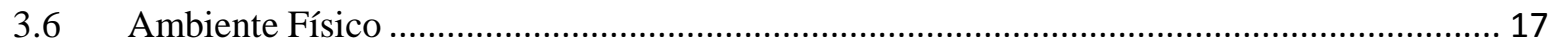

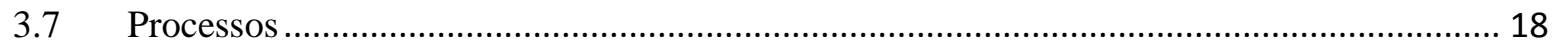

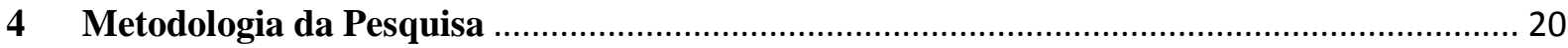

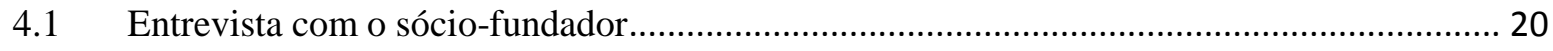

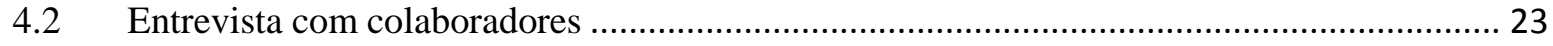

4.2.1 Entrevista com Aloísio Fernandes Cardoso ……………........................................... 23

4.2.2 Entrevista com Leonardo Dei Ricci ........................................................................... 25

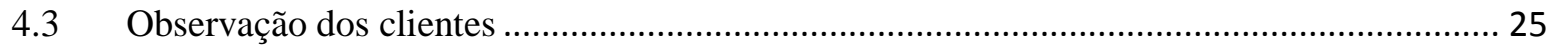

4.4 Cliente 1- Fábrica de Lubrificantes ................................................................................. 26

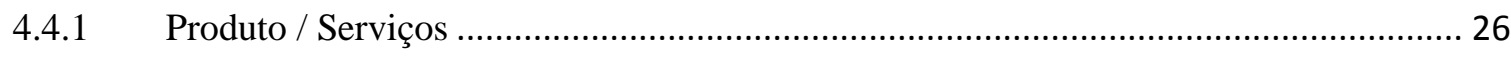

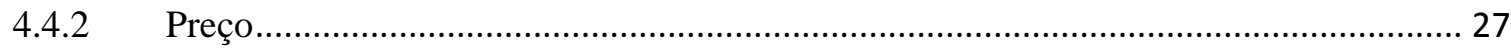

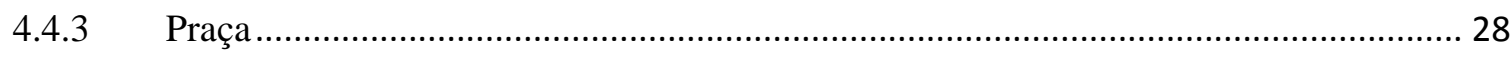

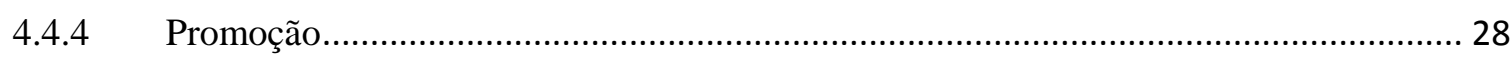

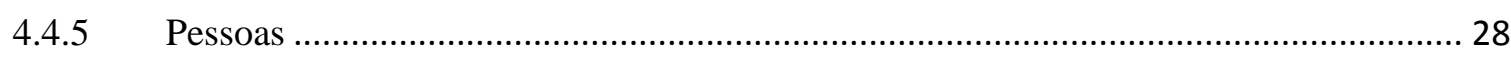

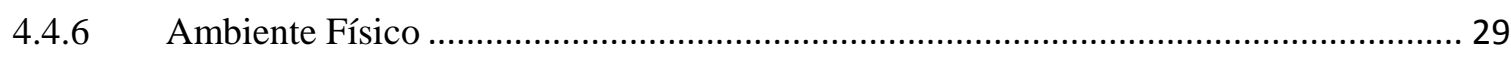

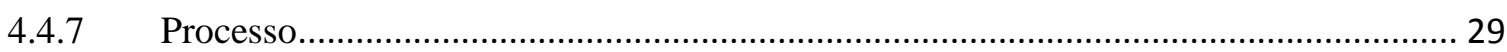

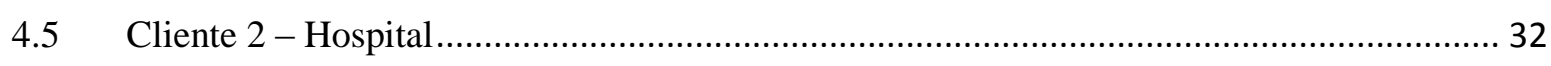

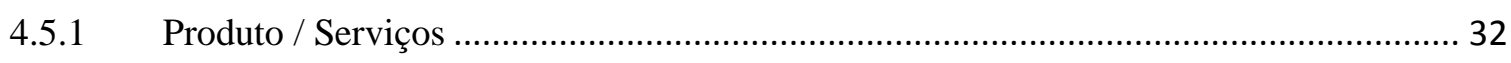

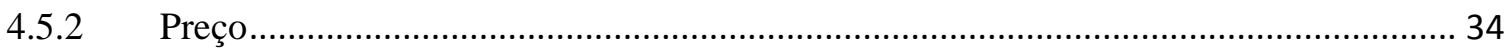




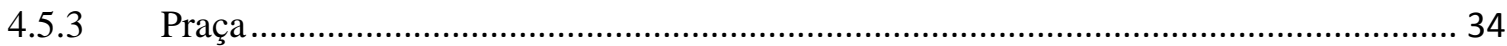

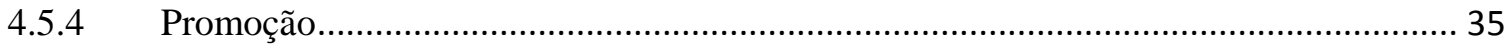

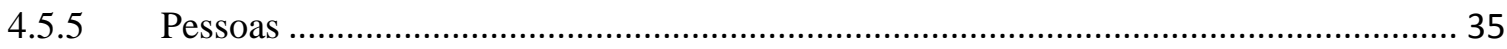

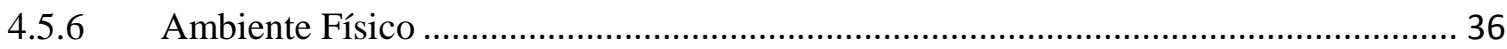

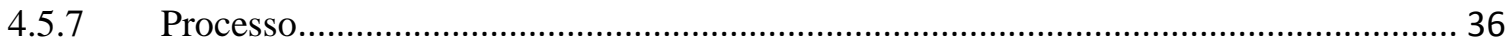

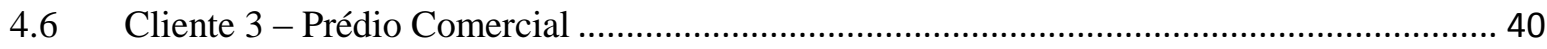

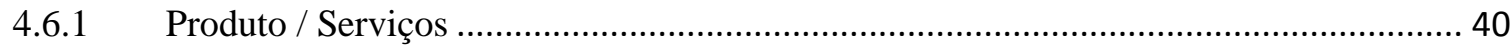

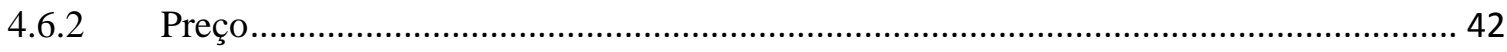

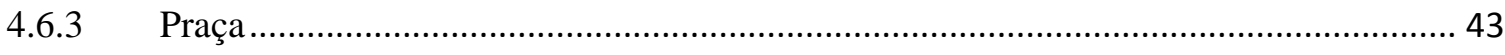

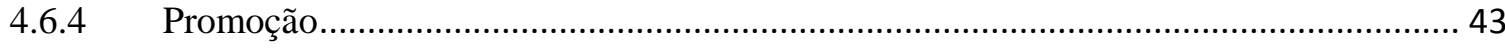

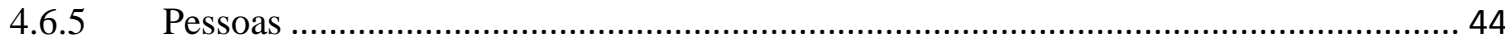

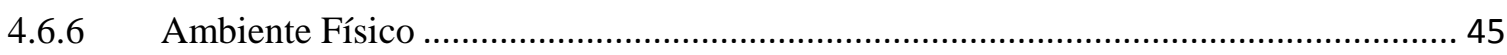

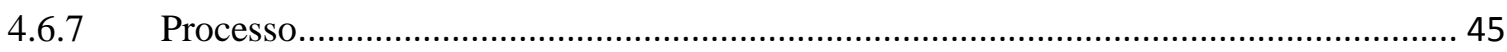

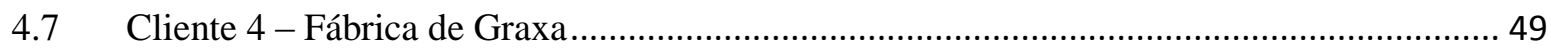

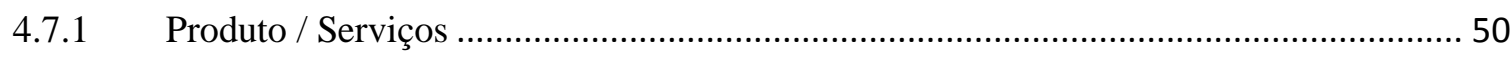

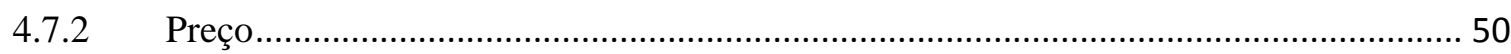

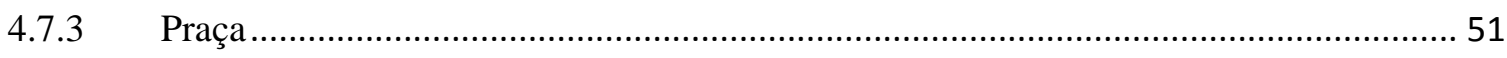

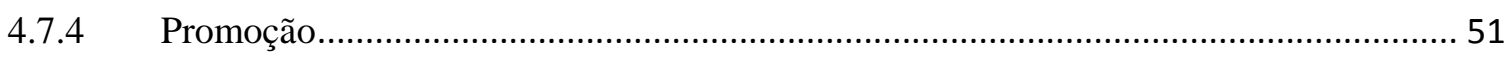

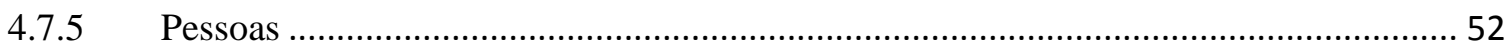

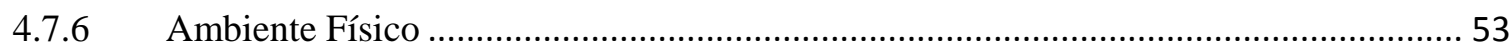

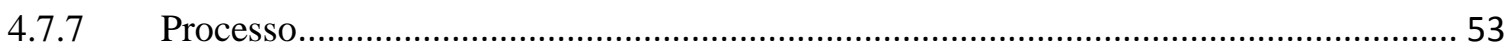

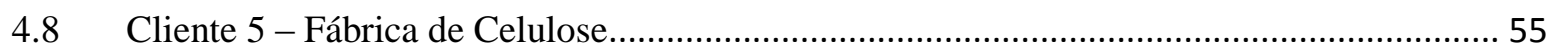

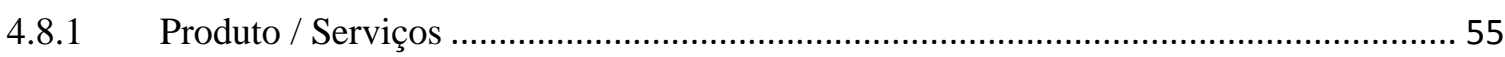

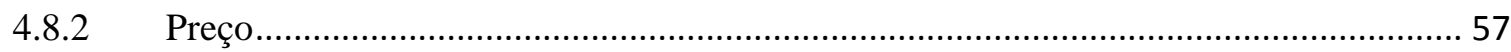

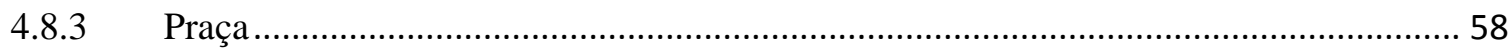

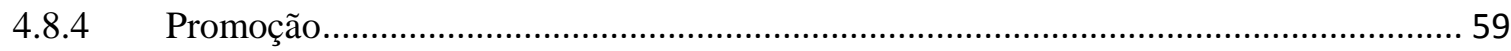

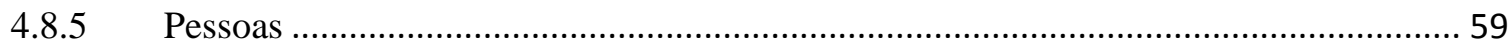

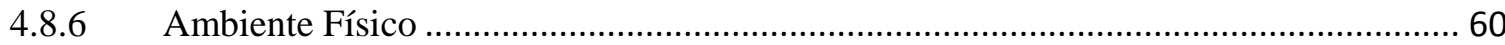

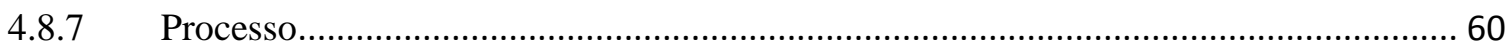

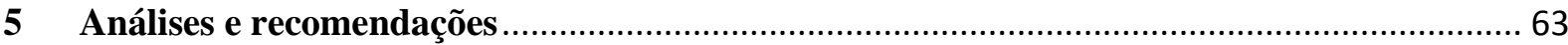

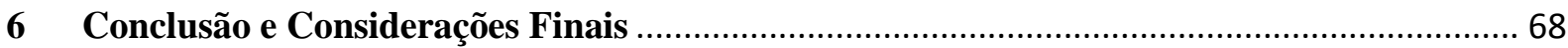

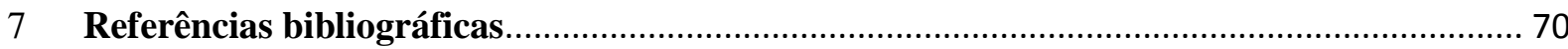

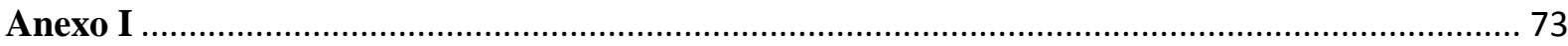

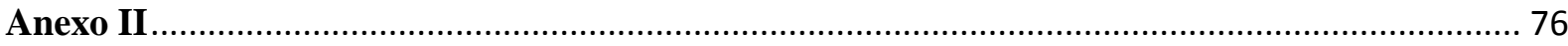




\section{Lista de Fotos}

Foto 1 Entrada do Edifício Comercial onde se estabelece a Empresa GSeabra ....................................... 2

Foto 2 Entrada da sala - utilizada como sala de reunião.................................................................. 3

Foto 3 Sala de trabalho e de coordenação dos Projetos de Perícia e Consultoria ................................... 3

\section{Lista de Figuras}

Figura 1 Informações retiradas do site da empresa .......................................................................... 3

Figura 2 Tendências de contratação de consultoria pelos setores ..................................................... 10

Figura 3 Fachada do prédio - equipamento - pórtico na cobertura e gôndola da manutenção ............... 41

\section{Lista de Quadros}

Quadro 1 Avaliação do Processo pela visão da GSeabra comparado ao do cliente 31

Quadro 2 Avaliação do Processo pela visão da GSeabra comparada à do cliente

Quadro 3 Avaliação do Processo pela visão da GSeabra comparada à do cliente .................................. 48

Quadro 4 Avaliação do Processo pela visão da GSeabra comparada à do cliente ................................ 54

Quadro 5 Avaliação do Processo pela visão da GSeabra comparada à do cliente ................................. 62 


\section{Introdução}

A necessidade de cumprir metas e objetivos organizacionais com eficácia e eficiência, prazos reduzidos e quadros de pessoal enxutos vêm levando as organizações a contratarem empresas de consultoria, buscando a realização de serviços específicos como execução de projetos ou diagnóstico de soluções que melhorem seu desempenho.

Existem oito fatores na consultoria que trazem importantes benefícios para a empresa que são: neutralidade, assertividade, avaliação de prioridades, uso de ferramentas e indicadores, diversidade, experiência, foco e agilidade. As empresas, em função das mudanças no mercado e na economia, precisam "reinventar modelos de negócio e otimizar os processos internos" para manter sua competitividade (PEREIRA, 2020).

Essa competitividade é um desafio ainda maior para o setor de serviços "quando é preciso determinar as estratégias para alcançar vantagens competitivas sobre os concorrentes. A forma ideal é elaborar uma composição de "mix de marketing para serviços" (SEBRAE, 2015).

Para Kotler (1998, p.97, apud Deboçã et al,2009) o composto de marketing ou o marketing mix é definido como: "o conjunto de ferramentas que a empresa usa para atingir seus objetivos de marketing no mercado-alvo", contudo foi visto que somente 4 P's criados por McCarthy ainda não eram suficientes para fazer a empresa prosperar, pois o cenário do marketing ficou mais complexo. Assim, este mix de marketing deveria possuir a visão do cliente, sendo criados mais 3 P's: pessoas, ambiente físico e processos (FALCÃO, 2005; KOTLER; KELLER,2012).

Este estudo terá como base a Empresa GSeabra Perícias e Consultoria e suas ações de marketing a partir do mix de serviços que compõe os 7p's. A história desta microempresa começa no ano de 2012, quando o engenheiro mecânico Sr. Guilherme E. Seabra, decidiu empreender no ramo de Consultoria e Perícias, após se desligar da organização onde trabalhou por mais de 30 anos, em empresa de grande porte da iniciativa privada, atuante no segmento de derivados de petróleo. Ter atuado em diferentes setores nesta organização, permitiu-lhe acumular uma bagagem profissional extremamente sólida, especialmente nas áreas de Segurança Industrial, Instalação e Manutenção, além de consolidar uma rede de networking. 


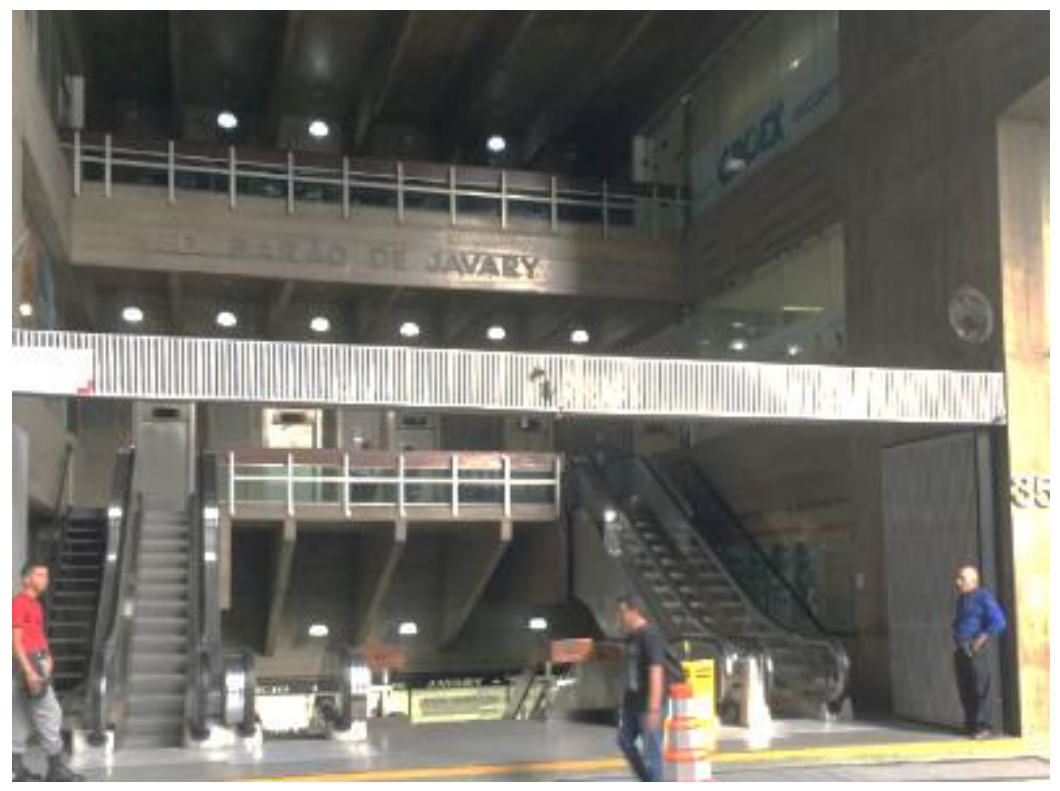

Foto 1 Entrada do Edifício Comercial onde se estabelece a Empresa GSeabra Fonte: Próprio autor

Ao fundar a GS (GSeabra), o objetivo do Sr. Guilherme era focar inicialmente somente no ramo de perícias. Contudo logo surgiram as primeiras demandas para prestação de serviços na área de consultoria, devido ao reconhecimento do mercado em relação à sua expertise profissional e devido ao seu networking, tendo sido um dos seus primeiros clientes a organização na qual trabalhou por tanto tempo. Assim, a GS começou a atuar em dois segmentos da engenharia, um voltado a Perícias e outro a Consultoria. Os trabalhos, em ambos os segmentos, eram desenvolvidos exclusivamente pelo sócio-fundador, com pequenas participações de alguns colaboradores.

a) Serviços de Perícia: dedicados a processos trabalhistas vinculados à competência do Fórum do Ministério do Trabalho ou a processos relacionados a acidentes, vistorias que dependem de conhecimentos técnicos de engenharia vinculados à competência do Fórum do Tribunal Estadual

b) Serviços de Consultoria: atendimentos a empresas privadas, onde se faz necessário desenvolver trabalhos de projetos e elaboração de normas e procedimentos para a metodologia de trabalho a ser implementada. 


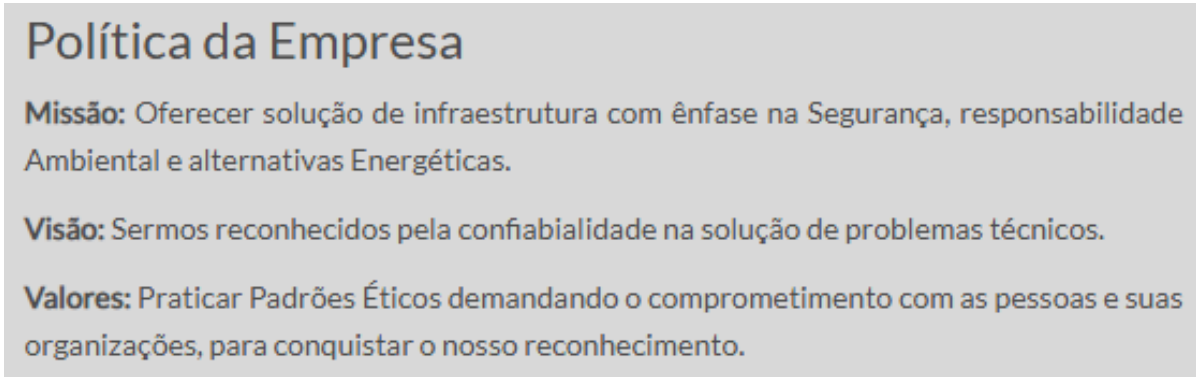

Figura 1 Informações retiradas do site da empresa Fonte: www.gseabra.com.br

O escritório dispõe de espaços para o trabalho do dia-a-dia e para reuniões com clientes e colaboradores, ambos equipados para videoconferências por meio de Skype.

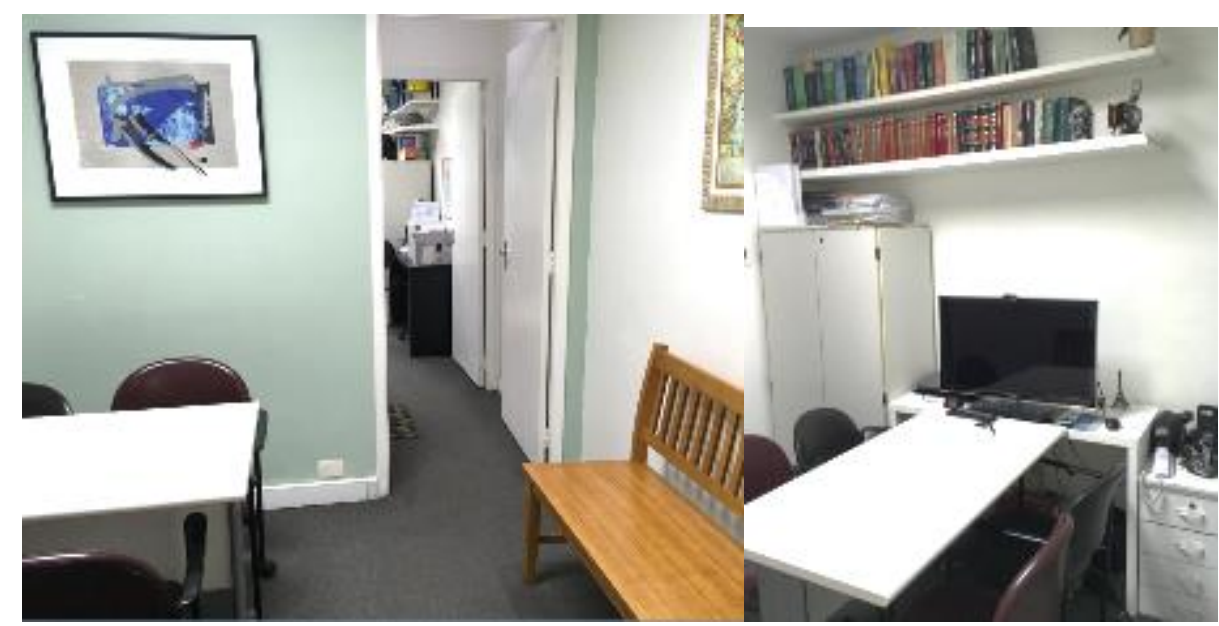

Foto 2 Entrada da sala - utilizada como sala de reunião Fonte: Próprio autor

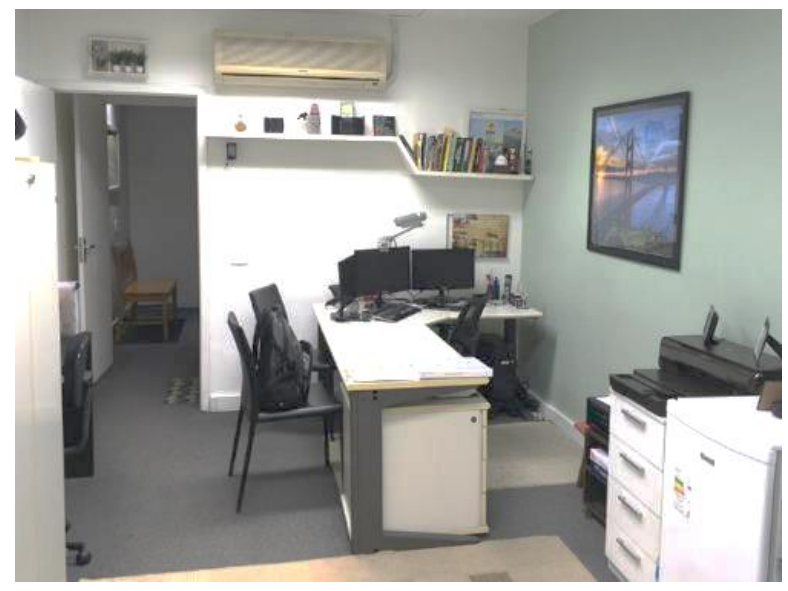

Foto 3 Sala de trabalho e de coordenação dos Projetos de Perícia e Consultoria Fonte: Próprio autor 
Desde a sua fundação em 2012, a GSeabra sempre priorizou o atendimento às demandas dos clientes e o cumprimento de prazos. Entre os anos de 2012 e 2014, nas eventuais sobreposições entre os projetos, era necessário aumentar a carga horária de trabalho para cumprir os prazos combinados, para não gerar impactos ou prejuízos no relacionamento com os clientes.

De 2014 a 2015, a empresa tornou-se mais reconhecida no mercado, aumentando a demanda de trabalhos e surgindo a necessidade de o sócio-fundador buscar uma equipe de profissionais para que a GS pudesse suportar as oportunidades que estavam sendo demandadas pelo mercado. A empresa passou a se dedicar ainda mais à consultoria e contar com uma equipe de colaboradores multidisciplinares, especializados em soluções de engenharia nas áreas de Elétrica, Civil, Mecânica, Ambiental e de Segurança ao Trabalhador, multiplicando a possibilidade dos diferentes tipos de prestação de serviços, não mais apoiada somente sobre a expertise do seu fundador e proprietário.

A partir de 2016, a economia nacional apresentou mais uma desaceleração no mercado, fazendo com que os clientes aplicassem cortes em seus orçamentos e reduzissem os investimentos. Esta mudança de cenário impactou a GS, pois na medida em que diminuíam as demandas dos clientes, o volume de trabalho tornou-se menor. Por não poder manter ocupada a equipe de colaboradores que havia sido formada anteriormente, a GS voltou a se dedicar com mais ênfase às Perícias Judiciais, devido à recessão econômica do país, que em paralelo deu origem a muitos processos Judiciais, naquele momento.

Após 2016, observando que a economia do país ainda permanecia pouco aquecida, o Sr. Guilherme decidiu repensar a visão de marketing perante o mercado. A GS estabeleceu uma nova estratégia comercial para expansão e sobrevivência da empresa, tendo como objetivo tornar-se mais competitiva. Constatando a continuidade do cenário negativo do mercado, a empresa começou a oferecer trabalhos a parceiros do mesmo ramo da engenharia, como alternativa de continuidade e aproveitamento da equipe multidisciplinar.

Dentre os trabalhos de consultoria da GS, iniciou-se a prestação de serviços na área de Segurança ao Trabalhador, pois a partir da inspeção nas instalações dos clientes é possível ser feita uma avaliação detalhada das fragilidades legais através de diagnósticos, para evitar danos ao empreendimento, possíveis ações trabalhistas de seus funcionários ou até mesmo multas pelo descumprimento de normas. 
De acordo com Santos (2018), existem diversos meios de infringir as normas vigentes, muitas passam despercebidas pelos supervisores das contratantes, com o valor podendo variar entre $\mathrm{R} \$ 636,17$ e $\mathrm{R} \$ 233.130,50$ conforme a gravidade do descumprimento da lei. Neste ofício, as bases para a declaração da multa são as Normas Regulamentadoras do antigo Ministério do Trabalho, que hoje pertence ao Ministério da Economia.

Além das atividades acima descritas, a GSeabra emite Parecer Técnico para as avaliações das fragilidades do cliente, gerando diversos documentos necessários para as soluções internas de engenharia ao desenvolvimento de projetos construtivos e levantamentos operacionais, tendo como clientes mais frequentes empresas de grande porte de diferentes segmentos de negócio.

A partir do cenário apresentado, este trabalho busca fazer uma análise baseada nos 7 p's de marketing visando melhorar sua posição como empresa de serviços no mercado. A monografia está estruturada da seguinte forma: (1) introdução incluindo a descrição e histórico da empresa; (2) contextualização do segmento na qual a empresa atua; (3) diagnóstico da situação problema e oportunidade; (4) entrevistas com o proprietário e seus colaboradores, enfatizando as respostas e opiniões mais marcantes e a pesquisa de observação dos clientes, com o enfoque em como se decorreu o serviço; (5) análise das entrevistas e das pesquisas de observações a partir dos 7p's, a fim de melhorar as estratégias de marketing; (6) conclusão contendo a análise de como a empresa está posicionada dentro dos 7 P's e respostas aos objetivos propostos neste estudo.

\subsection{Objetivos da pesquisa}

A pesquisa tem como objetivo final analisar os 7p's de marketing na organização objeto do estudo, a fim de identificar a existência de possíveis falhas e assim fazer recomendações no mix de serviços para consolidar a GSeabra no mercado.

Considerando-se o objetivo final desse estudo, devem ser atingidos os seguintes objetivos intermediários:

- Identificar os serviços apresentados pelo empreendimento (Produto)

- Analisar se o valor cobrado está de acordo com o serviço prestado e com a média do mercado onde o empreendimento está inserido (Preço)

- Analisar a localização do empreendimento em relação ao seu público-alvo (Praça) 
- Levantar como a empresa busca seus clientes e como se aproxima de clientes potenciais (Promoção)

- Identificar se os colaboradores do empreendimento compartilham a mesma visão de negócio da empresa e se possuem a qualificação necessária para atuação no segmento (Pessoas)

- Levantar qual o impacto do ambiente físico da empresa nos clientes (Ambiente Físico)

- Analisar se os métodos e o fluxo dos processos otimizam o trabalho dos colaboradores e se contribuem para a qualidade do serviço (Processos)

\subsection{Delimitação do estudo}

Para a realização desta pesquisa, teremos como objeto de estudo a empresa GSeabra, localizada na Rua da Ajuda número 35, sala 1003, Centro, Rio de Janeiro.

Este estudo foi realizado durante o segundo semestre de 2019 até o primeiro semestre de 2020, com uma empresa de pequeno porte, que se encontra em fase de expansão para maiores volumes de serviço.

Também é oportuno comunicar que este estudo sofreu consequências por conta da pandemia COVID 19 vigente. Por este motivo, foi realizada pesquisa de observação dos clientes através do histórico de e-mails, propostas, contrato, atas de reuniões, fotos e cronogramas e demais documentos encaminhados pela GSeabra aos contratantes.

\subsection{Relevância do estudo}

Este estudo será relevante para a empresa objeto da pesquisa, pois fornecerá uma nova perspectiva de ação sobre os 7 P's e novas oportunidades de negócio. Como consequência trará continuidade dos profissionais associados à GSeabra, visto que é uma necessidade da organização mantê-los com projetos em andamento de forma contínua. Além de contribuir para a fidelização de clientes e novas possibilidades de negócio.

Neste segmento, uma proposta para ser aprovada pelo contratante pode demandar tempo, pois o cliente analisa o projeto com cautela, em função dos custos envolvidos. Já o prestador de serviço investe tempo na elaboração das propostas, que muitas vezes não são aprovadas, gerando tempo perdido que poderia ser utilizado em outras frentes de trabalho. 
Assim, se a empresa possuir clientes fidelizados, aumentarão as chances do trâmite de aprovação da proposta ser mais rápida e com retorno positivo, possibilitando o crescimento da organização no mercado de serviços no qual está inserida.

\section{Contextualização}

Nesta sessão, serão apresentados e examinados dados e informações sobre o mercado em que a GSeabra está inserida, além de um aprofundamento sobre a ascensão do marketing de serviços e qual o seu impacto no setor de consultoria.

\subsection{A ascensão do Marketing de Serviços}

O serviço pode ser definido como:

"Qualquer ato ou desempenho, essencialmente intangível, que uma parte pode oferecer a outra e que não resulta na propriedade de nada. A execução de um serviço pode estar ou não ligada a um produto concreto.” (KOTLER, 2000, p.448, apud PORTAL EDUCAÇÃO,2013).

O marketing inicialmente surgiu atrelado à ideia de produtos. Somente em 1920 o marketing começou a se relacionar com serviços. Não se poderia imaginar que quase 100 anos depois o mundo iria mudar e os serviços iriam prevalecer sobre os produtos, tornando-se um setor de enorme importância na economia de um país (GRACIOSO,2013; PORTAL EDUCAÇÃO,2013).

Com a tecnologia se tornando cada vez mais presente na sociedade, as pessoas estão usando as facilidades disponíveis no mercado em função da comodidade e praticidade nos serviços oferecidos. O ponto positivo deste ápice na conveniência é a redução do uso de recursos naturais. Outro fator positivo dessa ascensão é o grande número de empregos oferecidos, graças à imensa diversificação que este setor possui.

O mercado de serviços, possui quatro pilares para o seu funcionamento, definidos como: intangibilidade, inseparabilidade, variabilidade e perecibilidade (KOTLER; KELLER, 2012, p. 384). A intangibilidade é determinada pelo fato de o resultado surgir após o serviço. Já a inseparabilidade é vista pela dependência da tarefa pelo prestador, pois sem ele não ocorrerá a atividade A variabilidade é observada pela diversificação da pessoa que realiza o serviço, ou seja, ela precisa estar preparada para fazer serviços distintos com qualidade. E a 
perecibilidade é definida pela longevidade da atividade, pois ela ocorre somente em um momento determinado, não podendo ser estocada. Entre todos os atributos que entrelaçam serviço com o marketing, Churchill e Peter (2000) focaram no esforço dos clientes e a relação com os consumidores, pois o esforço é essencial para o prestador de serviço entender o que o cliente almeja e assim realizar uma boa atividade. Já na relação vemos uma conexão duradoura com o comprador, que mostra confiabilidade e relacionamento entre quem faz e quem recebe a tarefa (KOTLER,2000; CHURCHILL; PETER, 2000; apud PORTAL EDUCAÇÃO, 2013).

Segundo o IBGE (Instituto Brasileiro de Geografia e Estatística), em 2017 existiam 1,3 milhões de empresas, um crescimento considerável se comparado com 2011, que possuía 1,1 milhões de empreendimentos deste ramo. A expansão deste mercado não se dá somente com o número de organizações novas, mas também com o faturamento e com a quantidade de empregados. Em 2011 possuíam quase R \$ 1 trilhão de receita e contavam com 11,4 milhões de funcionários, já hoje este setor conta com $\mathrm{R} \$ 1,5$ trilhões e pouco mais de 12 milhões de trabalhadores, respectivamente. Existem dados que comprovam este progresso do comércio de serviços, sendo o único setor que desfrutou de um melhoramento no PIB nacional de 2012, sendo responsável por $75 \%$ dos trabalhos formais e $67,5 \%$ do PIB brasileiro. O setor de serviços já correspondia em 2017 a 70\% do PIB brasileiro, e mesmo com a crise econômica e política que o Brasil vivia na época, esta área teve aumento de 0,6\% (MELO; VELASCO, 2017).

O marketing de serviços pode ser entendido como:

“Atividades operacionais destinadas a investigar, obter e servir a demanda por assistência profissional (...) objetivando investigar a oportunidade de mercado para panejar, organizar e oferecer assistência de serviços de qualidade, a preços razoáveis que possibilitem satisfação dos clientes e remuneração adequada aos profissionais. " (FILHO, 2001, apud POSSETI, 2010).

Percebe-se que o marketing de serviços é essencial nas organizações para se poder entender melhor os clientes e as formas mais eficazes de vendas (PONTES,2013). Na visão do IBC (Instituto Brasileiro de Coaching) o marketing de serviços organiza melhor a estratégia de marketing que a empresa terá que percorrer para atrair o consumidor. Fazendo o cliente apreciar o serviço, a ponto de se fidelizar com a organização, além de adquirir um maior espaço no mercado que está inserido para assim reter lucros. Para isso ocorrer, a 
corporação necessita inovar, aproximar-se do comprador e ser sempre pontual na entrega do serviço oferecido. Em outras palavras, o marketing de serviços coloca em primeiro lugar os clientes, o que é essencial para o serviço ser eficiente, e para isso, esta teoria reúne informações para analisar o mercado ou o público-alvo. Desta forma, pode planejar uma ação mais competente e de fácil implementação, tendo assim o controle absoluto dos planos para a entrega de um serviço no tempo prometido e com a qualidade pretendida, alcançando a satisfação e confiabilidade do consumidor perante a empresa. Assim a organização consegue reter clientes e aumenta a oportunidade de possuir mais potenciais consumidores, pois eles se sentem parte da empresa, já que ela oferece todo o suporte para ajuda dos compradores antes, durante e após o serviço ser realizado.

Porém, para este marketing de serviços ser eficiente, é necessário que o gestor tenha conhecimento do mercado em que a empresa está inserida e que os colaboradores realizem com eficiência o que foi treinado e entendam o ponto de vista dos compradores. De acordo com a IBC (Instituto Brasileiro de Coaching), para uma estratégia de marketing de serviço ser competente é preciso priorizar a utilização de quatro critérios: qualidade do que foi realizado, uma boa aplicação dos 7 P's, um contato com o comprador eficaz e claro, uma comunicação constante com os consumidores.

\subsection{Mercado de Consultoria no Brasil}

Em 2017, o Brasil alcançou o número de 27,4 milhões de indivíduos que abriram a sua própria empresa. E foi verificado, que no território brasileiro existem praticamente 50 milhões de empresários. Tendo como base os dados da GEM (Global Entrepreneurship Monitor, 2017) (SANTOS,2018). De acordo com Romano (2019), o setor privado é o que mais demanda deste segmento com $83,2 \%$, seguido pelo terceiro setor em segundo, porém bem distante do setor privado. Além do crescimento no número de pessoas que não querem estar presas a um único ramo de atuação, a crise econômica vivida pelo país fez com que aumentasse a quantidade de interessados em abrir novas empresas de consultoria.

As corporações observaram que para terem vantagem competitiva precisavam distinguir-se das organizações já existentes, visto que a quantidade de compradores estava cada vez menor. Assim, foram em busca de consultorias, para poderem identificar as falhas existentes, a fim de eliminarem esses impasses e tornarem a empresa mais competitiva (INTELLIPLAN, 2016). 
Existem quatro motivos para a escolha de contratar empresas deste ramo, que são: a dificuldade dos gestores em encontrar o problema; não ter conhecimento para consertar o causador do defeito; não possuir mão-de-obra para corrigir; ter um elemento neutro, externo à organização, para propor as medidas necessárias, pois nem sempre são medidas que agradam os funcionários, o que poderia gerar adversidades caso fossem determinadas pelos gestores e assim abaixar a eficiência e eficácia (SIBROM,2017).

O grande número de novas empresas em diversos ramos faz o mercado em questão expandir-se, pois a organização que tenha lacuna de conhecimento irá contratar uma consultoria para rever o planejamento prévio, gestão empresarial e comportamento do empreendedor, visto que são os motivos cruciais para a falha de gestão nos primeiros cinco anos desde a sua criação (SANTOS, 2018).

Apesar dos benefícios da consultoria, muitas empresas de médio ou pequeno porte consideram que a consultoria não é benéfica ao seu empreendimento, sendo válido apenas para empresas de grande porte. Porém a contratação de uma consultoria traz um diferencial considerável independente do porte que a empresa possui, pois possibilita um conhecimento mais específico do setor e assim um maior entendimento sobre seus clientes, concorrentes, tendências, oportunidades e riscos. Com esse aprofundamento sobre o mercado, a corporação irá tomar decisões mais corretas na hora de fazer investimentos. $\mathrm{O}$ aumento das vendas também está diretamente relacionado com os serviços de consultoria, já que com a empresa tendo uma consciência maior do seu setor, será possível realizar ações comerciais e de marketing mais precisas e mais impactantes (INTELLIPLAN, 2016).

\section{Tendências da contratação de} Consultoria pelos Setores

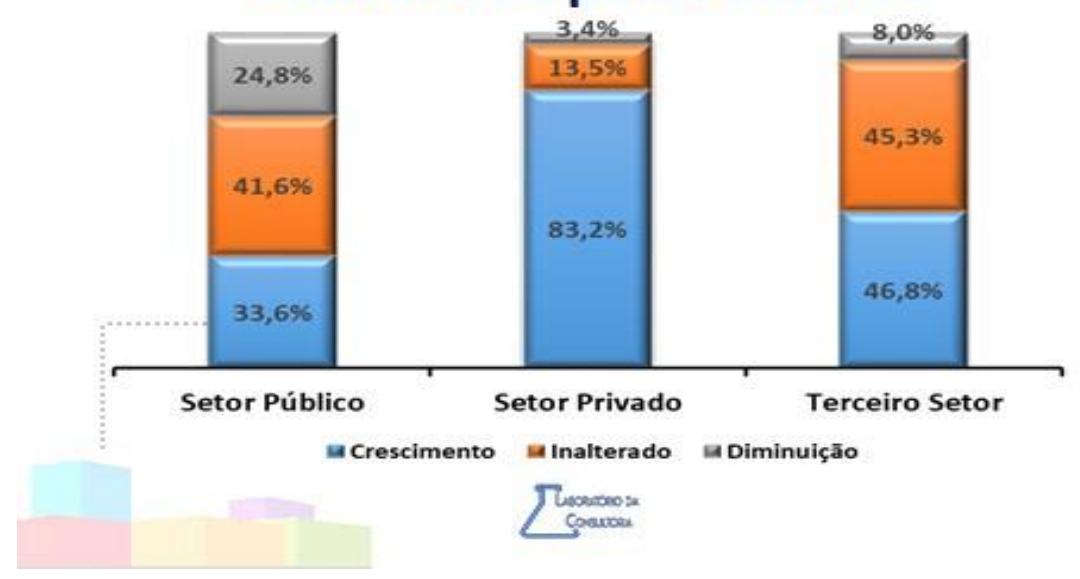

Figura 2 Tendências de contratação de consultoria pelos setores 


\subsubsection{Segmento de Normas Regulamentadoras do Brasil}

Existem dois tipos de normas que são utilizadas pela GSeabra em seus trabalhos de Perícia e Consultoria, as quais norteiam as corretas práticas da Engenharia. São elas:

a) Pela ABNT (Associação Brasileira de Normas Técnicas)

São aplicadas nas situações onde há necessidades técnicas ligadas à construção ou funcionamento do empreendimento e são utilizadas de forma orientativa, porém passam a ser exigidas quando mencionadas por meio de Leis e Portarias, tornando-se obrigatórias para a promoção da segurança industrial.

b) Pela NR (Normas Regulamentadoras)

As normas regulamentadoras foram elaboradas com base nas diretrizes aplicáveis de forma legal, amparadas ao uso jurídico, e têm como finalidade preservar a saúde ao trabalhador e em sua maioria, atender os diferentes segmentos de indústrias, as quais são obrigatórias para a segurança ao trabalhador pelo antigo Ministério do Trabalho, incorporado ao atual Ministério da Economia (NETO, 2012).

As normas regulamentadoras são essenciais para uma desenvoltura mais segura no ambiente profissional, tentando ter uma precaução sobre os riscos ao contratado, seja físico ou a saúde do profissional. Os responsáveis pelo desenvolvimento das normas são: "Ministério do Trabalho adotando o sistema tripartite paritário por meio de grupos e comissões compostas por representantes do governo, de empregadores e de empregados " (ENIT, 2020).

Dentre as Normas Regulamentadoras, destacam-se: PPRA (Programa de Prevenção de Riscos Ambientais), PCMSO (Programa de Controle Médico de Saúde Ocupacional), PPP (Perfil Profissiográfico Previdenciário), CIPA (Comissão Interna de Prevenção de Acidentes), ASO (Atestado de Saúde Ocupacional), LTCAT (Laudo Técnico das Condições do Ambiente de Trabalho), Laudo de Insalubridade, Ficha de EPI (Equipamentos de Proteção Individual) e Mapa de Risco (CONECT,2018). 
Um fato que chama a atenção neste segmento é a terceirização. Em 2017, o então presidente Michael Temer aprovou um projeto com ajuda dos deputados, sobre a liberação da terceirização de empresas ou pessoas para quaisquer atividades da organização, trazendo assim um maior crescimento das firmas de serviços, já que este projeto deixava mais às claras a relação da terceirização com os vínculos trabalhistas (CASTILHOS, 2017).

Neste segmento existem várias empresas de consultorias que se especializam em determinado ramo de atuação, escolhendo um segmento de norma a ser utilizado, ABNT ou NR.

No caso da GSeabra, tanto as normas da ABNT como as da NR são aplicadas nas prestações de serviço, tanto nas Perícias Judiciais como nas consultorias voltadas exclusivamente para a Engenharia.

\section{Diagnóstico da Situação Problema e Oportunidades}

\subsection{Produto / Serviço}

Kotler e Keller (2012) consideram que o produto não é algo tangível ou durável, mas é aquilo que a empresa está comercializando no mercado, podendo ser tanto um bem como um serviço, que trará retorno à organização e ao mesmo tempo atrairá o cliente.

No mix de produtos, observa-se também a venda de serviços ou produtos que se completam, ou seja, para um produto funcionar é necessário outro produto da mesma empresa, fazendo assim o consumidor adquirir bens da mesma organização (KOTLER; KELLER, 2012).

Com base na visão de Kotler e Keller (2012), a GSeabra passou por uma grande mudança nos serviços oferecidos. Iniciou prestando serviços em perícias judiciais com base nas Normas Regulamentadoras do Trabalho, passando em seguida a atuar no ramo de consultoria de serviços em projetos de engenharia para empresas da iniciativa privada na área da mecânica, civil ou elétrica.

A diferença da prestação destes serviços da GSeabra ocorre pela ênfase da segurança e consequentemente pela redução de riscos de acidentes. Um aspecto valorizado pelos clientes é a experiência nas atividades de perícia judicial.

A venda cruzada pela GSeabra não é o objetivo principal da empresa, pois a ênfase está em oferecer o serviço para solucionar o que foi pedido pelo cliente. Contudo, ao longo da 
evolução do trabalho, problemas são identificados que promovem a demanda por novos serviços, para a adequação necessária no empreendimento.

Tentando ter este $\mathrm{P}$ mais favorável, a empresa tenta diferenciar-se dos concorrentes e procura conseguir uma crítica positiva de cada um dos seus serviços. A organização oferece um conjunto de soluções, combinando a engenharia de construção aliada com a segurança em um só projeto, e trazendo assim mais praticidade e tranquilidade para os clientes, ao identificar perigo de ocorrências negativas na área operacional do negócio.

\subsection{Preço}

O preço também faz parte do mix de marketing. Nele temos o valor regulado pela empresa para a locação do produto ou serviço no mercado (MIGRE SEU NEGÓCIO, 2017).

Vale ressaltar que este é um dos P's mais importantes, já que é com ele que o retorno financeiro e, consequentemente um futuro lucrativo, é esperado pela empresa. Neste P, não é somente o valor monetário que é abordado, mas também o valor psicológico que causa nas pessoas, podendo-se dizer que é “ a soma de todos os valores que os consumidores trocam pelos benefícios de ter ou usar um bem ou serviço" (CARDOSO, 2016).

O preço precisa ser bastante analisado, pois um preço muito baixo afasta os clientes, os quais entendem que o produto ou serviço não irá suprir as expectativas criadas. Por outro lado, um preço muito alto também provoca rejeição nos clientes, por não se sentirem psicologicamente confortáveis para fazer um investimento muito alto (MIGRE SEU NEGÓCIO, 2017).

Segundo Kotler e Keller (2012, p.24), dentro do conceito preço existem subtópicos que seriam "preço de lista, descontos, bonificações, prazo de pagamento e condições de financiamento".

No serviço apresentado pela GSeabra, o preço varia dependendo do tempo gasto na elaboração de cada projeto. Visando calcular o valor do serviço, é necessário ter como base o custo para a execução do serviço, de forma a não haver prejuízo. Assim a empresa utiliza a conversão do tempo de execução da tarefa para definir o valor final do trabalho.

Para que os clientes se disponham a pagar valores mais altos é necessário que estes percebam que o serviço será feito com qualidade, rapidez e precisão. Neste mercado, uma diminuição pequena no valor a ser cobrado não impacta diretamente nas vendas, isso é 
explicado através da percepção do cliente, que se baseia no preço inicial para assim ter uma base nos próximos serviços, havendo possibilidade de desvalorizar o projeto ofertado na visão do consumidor para os próximos serviços. Por outro lado, na redução do valor final, possui chances de viabilizar uma maior quantidade de negócios por conta do preço.

Em relação aos valores de mercado, comparado com a concorrência, o preço que vem sendo praticado pela GSeabra está em linha com os concorrentes, porém neste mercado a comparação é difícil de ser feita por este tipo de medição, pois cada projeto se distingue pelas suas próprias características técnicas.

A GSeabra tem como política conceder descontos aos seus clientes, nos casos em que demandam um volume maior de trabalho.

\subsection{Promoção}

Podemos ver nesse $\mathrm{P}$, o impulsionamento da marca ou serviço no ambiente que a empresa se encontra, tendo como objetivo principal trazer clientes que possuem os mesmos desejos que a organização promove, tendo como propósito, aumentar as vendas, e como consequência impulsionar o valor da marca no mercado. Este P, é de extrema importância para as informações do serviço ou produto chegarem nos consumidores corretos. Para esse mix ser perfeito precisa ser escolhida a forma de mensagem que o gestor deseja transmitir, o público-alvo e o orçamento, se a empresa possui capital ou não (MIGRE SEU NEGÓCIO, 2017; SEBRAE, 2015).

Para a GSeabra impactar com mais intensidade o seu público-alvo é necessário ter um conhecimento sólido sobre cada um eles. No caso da GSeabra são atendidos dois tipos distintos de clientes:

a) Juízes e advogados: segmento referente à perícia, onde existe conexão com os tribunais de justiça;

b) Empresas privadas: com foco na consultoria em engenharia, estes clientes são de diversos segmentos que solicitam serviços para a GSeabra.

Para este público-alvo a empresa investe em visitas constantes a clientes, aceitação de convites em aulas em diferentes instituições, participação em feiras ou seminários e networking, a fim de conquistar novos consumidores. A empresa pensa em expandir-se mais neste $\mathrm{P}$ e vem levando em consideração a colocação de propagandas nos meios eletrônicos e 
digitais, porém a ideia ainda é embrionária, por conta disso, ainda não foi desenvolvida nenhuma estratégia para esta implementação.

Focando em um melhoramento da promoção, a empresa criou um site, a fim de facilitar o contato com os clientes. Apesar do website ser apresentado de forma clara e simples, destacando os serviços oferecidos pela GSeabra, não é utilizado pelos potenciais clientes para novos serviços.

\subsection{Praça}

Este $\mathrm{P}$, também pode ser chamado de distribuição, pois é com a praça que podemos ver a relação de produto e consumidor, ou seja, neste $\mathrm{P}$ colocamos o produto ou serviço em contato com o cliente. Assim está presente não somente o consumidor, mas todos os fornecedores e revendedores de empresas e fabricantes de equipamentos. Também é levado em consideração se o local que a empresa escolheu situar-se é de fácil acesso tendo em vista os seus clientes potenciais, pois caso contrário darão preferência aos concorrentes mais próximos (MIGRE SEU NEGÓCIO, 2017).

A internet é de extrema importância para a visualização dos clientes, visto que antes da procura em campo, sempre existe a procura online. É importante definir se o serviço oferecido será através de canais próprios ou canais de terceiros e tomando cuidado para estes terceiros não acabarem trazendo uma má imagem aos consumidores. Sendo assim, este P tem como fatores essenciais para a sua decisão os "canais, cobertura, sortimentos, locais, estoques e transporte" (KOTLER; KELLER, p.24, 2012).

Vemos que a praça são os canais de distribuições necessários para o produto chegar no cliente. Com isso, vemos que este $\mathrm{P}$ engloba como a empresa irá disponibilizar o produto para o consumidor, desde o período antes da entrega até o modo como a organização disponibilizará o produto ao comprador (SEBRAE, 2015).

Um dos maiores desafios da GSeabra dentro da praça é conectar os dois ramos, ou seja, Perícia e Consultoria na engenharia, visto que eles possuem perfis distintos. Enquanto nas perícias judiciais os juízes buscam registros profissionais que estejam na base de dados do Tribunal de Justiça, os advogados procuram por laudos no portal do Tribunal de Justiça. Já nas consultorias de engenharia esta pesquisa se dá por indicações de empresas que já contrataram serviços da GSeabra e pelo networking. 
A GSeabra, por não possuir colaboradores dedicados especificamente para a venda por canal, precisa investir na divulgação de serviços para mostrar sua diferença em relação aos concorrentes e para alcançar novos clientes. Observa-se que a organização utiliza canal próprio para fazer a comercialização do seu serviço, sendo o mais forte o networking do seu sócio-fundador e em menor escala o networking dos colaboradores.

\subsection{Pessoas}

Este $\mathrm{P}$ está relacionado na forma pela qual o serviço irá atingir o cliente final, seja no contato direto com o mesmo ou na realização de tarefas não visíveis para o consumidor. Sendo necessário a capacitação dos integrantes da empresa para que eles realizem um serviço de qualidade com o intuito de ser percebido pelo comprador (SEBRAE, 2015).

Kotler e Keller (2012 p.24) destacam que:

As pessoas refletem, em parte, o marketing interno e o fato de que os funcionários são fundamentais para o sucesso do marketing. Este será tão bom quanto as pessoas dentro da organização. Também refletem o fato de que as empresas devem ver os consumidores como pessoas e compreender suas vidas em toda sua amplitude, e não apenas como alguém que compra e consome produtos.

Destaca-se a importância do marketing de relacionamento para este $\mathrm{P}$, já que os integrantes da empresa que realizam o serviço são fundamentais para trazer uma boa crítica para a organização. Sendo assim, uma vantagem competitiva, caso a empresa tenha empregados engajados em irem além do que é esperado pelo comprador. Para isto acontecer, é necessário dar um bom treinamento para eles, a fim dos funcionários estarem alinhados na forma com que a corporação pretende ser vista no mercado (MIGRE SEU NEGÓCIO, 2017). Os responsáveis pelo contato com o cliente fazem parte da experiência do comprador com a empresa. (SEBRAE, 2015).

Um fator significativo neste $\mathrm{P}$ é a forma como os colaboradores da empresa se relacionam com os clientes. Na GSeabra, os colaboradores possuem perfil técnico para a realização das tarefas, contudo não possuem conhecimento sobre metodologias de abordagens de vendas. Os colaboradores que possuem mais habilidades interpessoais seguem um roteiro que funciona como base para se comunicar com o cliente, uma listagem de perguntas e respostas para usarem no momento do contato com estes. 
Mesmo não possuindo um treinamento específico na área comercial, os colaboradores conseguem conquistar os clientes por sua atenção e educação, além de serem bons ouvintes para entenderem os mínimos detalhes do que o consumidor deseja.

Observa-se que os colaboradores estão motivados pelo potencial que a GSeabra tem no mercado, estando sempre disponíveis para comparecer a eventos que serão importantes no networking de novos clientes, alinhados com a missão e visão da empresa.

\subsection{Ambiente Físico}

O P do ambiente físico dá-se no momento em que o cliente entra em contato com a empresa, ou seja, quando o mesmo avalia o ambiente, seja pelo tamanho, móveis, cores das paredes ou qualquer aspecto tangível. O consumidor tende a reparar e julgar todos os detalhes da empresa ou da loja e assim criar uma percepção sobre a mesma. É por isso que este P também é chamado de percepção ou evidências físicas. A diferença do ambiente físico para praça é que enquanto praça foca mais no local onde o empreendimento ou a loja estão estabelecidos para a realização da venda, o ambiente físico destaca a visão do cliente no momento em que entra no ambiente onde a empresa se encontra (MIGRE SEU NEGÓCIO, 2017).

O ambiente físico ocorre quando o cliente cria um pensamento sobre a organização e assim deduz o que pode esperar do estabelecimento. Este prognóstico por parte do consumidor, acontece pelos mínimos detalhes, desde a forma como é atendido pelos funcionários até o modo da empresa pintar as paredes. Resumindo, basicamente este P definese pela forma como o comprador é abordado pelos contratados ou empregados e pelo estado do local onde o empreendimento se encontra, assim que entra em contato com a empresa (SEBRAE, 2015).

Quando o cliente tem o primeiro contato com a organização ou serviço, o P de percepção entra instantaneamente em ação, mesmo que o cliente não perceba. Os mínimos detalhes do local ou serviço são de extrema importância para atrair os compradores, seja na decoração ou até na limpeza. Cada cliente terá uma percepção dependendo do que ele almeja, se a decoração é mais moderna, ele pode tender a achar que a empresa possui novas tecnologias, mas com uma decoração mais tradicional, ele pode achar que a organização é mais séria e antiga no mercado. 
Apesar do local onde a GSeabra se encontra ser bem localizado, por estar no Centro e em frente à uma estação do metrô, o espaço é considerado pequeno tanto pelo fundador quanto pelos colaboradores. O local do escritório onde são realizadas as reuniões não é satisfatório por ser muito perto da entrada e saída do escritório e com espaço insuficiente para circulação. A sala principal não permite a colocação de mais mesas de trabalho.

Já que o Ambiente Físico é tudo o que o cliente percebe sobre o contratado, a vestimenta torna-se importante neste P. Os integrantes do empreendimento base deste estudo sempre se encontram com os contratantes trajando camisas sociais ou polo, além de sempre estarem de calça e sapatos, mostrando a formalidade da empresa perante o consumidor. Outro ponto a ser destacado é o cartão de visita oferecido, o qual não possui informações pessoais, contendo somente o nome da GSeabra, o telefone ou celular, o site e onde está localizada. Por fim, temos o relatório, o qual está sempre bem escrito e formulado, já que o revisor do relatório é o próprio sócio-fundador.

Ressalta-se que em função da natureza do trabalho é muito mais frequente a GSeabra ir até os clientes do que vice-versa. Contudo, alguns clientes que estiveram no escritório comentaram que haveria mais conforto para os colaboradores se a empresa possuísse instalações mais amplas.

\subsection{Processos}

A qualidade da gestão dos processos tem sido cada vez mais utilizada nas empresas como um diferencial competitivo.

Os processos e modelos que integram o universo dessa temática possibilitam o contínuo aperfeiçoamento das empresas, que, a todo instante, são conduzidas a alterar suas sistemáticas e seus procedimentos, na tentativa de atingir maiores patamares de competitividade. (JUNIOR et al., 2012, p. 16).

Os processos em marketing são os métodos utilizados pela empresa para que o serviço chegue ao cliente, em outras palavras, são os procedimentos que a empresa opera para entregar um serviço ao consumidor. Além de englobar os primeiros contatos com o cliente até o pós-venda, este P ajuda a "diferenciar o nível de qualidade do serviço", pois o comprador precisa se aproximar da forma com que a organização atua para assim entender 
melhor como a mesma opera. Caso o processo seja mal projetado, a satisfação do cliente irá diminuir, além da própria produtividade da corporação. E assim, atrapalhará o mix de marketing de serviços (MIGRE SEU NEGÓCIO, 2017).

É importante que os colaboradores estejam informados das ações de processos que a empresa atua e treinados para executar de forma eficiente o processo. Este $\mathrm{P}$ é totalmente relevante para a empresa ter sucesso ou fracasso, quando inserida em serviços (SEBRAE, 2015).

Na GSeabra, o processo inicia-se pelo contato do cliente por meio de telefone ou correio eletrônico. Após este contato inicial é agendada uma reunião presencial ou via internet (Skype). E logo depois é enviada ao cliente a proposta para o desenvolvimento do trabalho com os itens que a GSeabra pode oferecer, a partir do que foi discutido na reunião inicial. Se a solicitação do cliente for uma atividade de pequeno ou médio porte, o tempo de entrega do trabalho será de uma semana, mas se a tarefa for de grande porte, o período pode se estender de 40 a 60 dias. Diversas vezes o contratante retorna o contato para ter mais informações sobre as razões do preço e a respeito das questões técnicas das etapas que não foram entendidas. Enquanto nas consultorias é de costume a realização de visitas técnicas para se fazer a proposta, nas perícias estas visitas são obrigatórias.

Visando um maior entendimento do cliente, os colaboradores da GSeabra explicam as etapas necessárias para a execução do serviço ou projeto a ser realizado. Normalmente o cliente entende e aceita o prazo de realização, porém quando o contratante necessita um prazo de entrega muito reduzido, a GS não consegue atendê-lo, o que pode levá-lo a buscar empresas concorrentes devido a urgência, porém o cliente fica vulnerável em não alcançar a qualidade final esperada pelo trabalho.

Além deste fator, a organização busca a participação dos consumidores nas etapas da realização do projeto, dividindo o serviço em três partes. A primeira é referente ao rascunho do projeto ou estudo que será elaborado. Depois o projeto preliminar é apresentado de forma mais detalhada, informando sobre como o trabalho será executado. E por fim é entregue o projeto final, composto por documentos diversos, com uma estrutura de fácil entendimento, que se assemelha a um laudo de perícia.

Buscando a satisfação dos clientes, é realizada uma reunião detalhada das etapas do projeto e o tempo estimado para executá-lo antes do aceite da proposta. Caso ocorram atrasos, os clientes recebem antecipadamente uma explicação com fatos que motivaram a demora. 


\section{Metodologia da Pesquisa}

Esta pesquisa será considerada como exploratória de natureza qualitativa. Foram realizadas entrevistas com três integrantes da GSeabra, o sócio-fundador, e dois colaboradores e, em função da pandemia, foi realizada uma pesquisa de observação com cinco clientes, analisando-se como se desenvolveu a prestação de serviços.

Nesta análise, foram utilizados dados secundários sobre a empresa, e-mails, cronogramas, atas de reunião, desenhos da estrutura das instalações do contratante e propostas comerciais.

\subsection{Entrevista com o sócio-fundador}

O entrevistado foi indagado de forma sucinta e direta sobre perguntas específicas e ao mesmo tempo ficou livre para pronunciar-se sobre qualquer tema que ele presumia ser desafiador para a GSeabra.

A entrevista ocorreu no dia 31 de outubro de 2019, de $10 \mathrm{~h}$ até as $12 \mathrm{~h}$.

$\mathrm{Na}$ entrevista com o Sr. Guilherme, este afirmou que o local onde a empresa se encontra atende as suas necessidades, visto que se encontra próxima de um dos seus públicosalvo, o Fórum do Tribunal do Estado do Rio de Janeiro, além da facilidade de acesso aos seus clientes, por estar em frente a uma das saídas do metrô.

O entrevistado também comentou sobre o interesse de ter um escritório maior e de reunir de forma mais frequente os seus colaboradores, aumentando a integração entre eles, com o intuito de aumentar a velocidade na finalização dos projetos. Outro ponto manifestado na entrevista foi a vontade de atuar fora do Estado do Rio de Janeiro. Para isso o Sr. Guilherme almeja o uso de plataformas digitais, aliado às ferramentas de comunicação à distância para acelerar o desenvolvimento de execução dos serviços, eliminando as despesas de logística com deslocamentos, tornando a empresa mais competitiva com as concorrentes destas localidades.

Informou ainda que solicita aos colaboradores que utilizem vestimenta adequada no escritório e principalmente quando encontrarem os clientes. Sobre o cartão de visita, na visão do sócio-fundador, as informações contidas nele estão de acordo com que o mesmo quer 
transmitir para os consumidores, pois mais dados iriam trazer uma experiência visual ruim. Sobre a qualidade dos relatórios, acredita que conseguem trazer alto valor agregado ao serviço, mas o sócio-proprietário necessita revisar o que os colaboradores escrevem, para corrigir a formatação e ortografia.

Outro ponto que foi explorado na entrevista refere-se à formação de preço que a GSeabra cobra dos seus clientes. Neste tópico, o sócio-fundador afirmou que o valor cobrado é menor se comparado com outros serviços ofertados no mercado. Isto acontece, pois, a atividade prestada resulta em: "valor agregado ao resultado do cliente é de grande retorno para a empresa contratante, pois disponibiliza diversas soluções voltadas para a engenharia que se baseia o seu negócio”.

Com o crescimento de demandas geradas pelo mercado de serviços, surgiram diversas empresas de consultorias e, assim, a competitividade ficou cada vez mais acirrada e os preços foram drasticamente reduzidos, porém sem prezar tanto pela qualidade, mas de grande atratividade aos clientes.

Este fato foi um dos pontos observados pela GSeabra para oferecer ao mercado um modelo diferenciado de serviços em relação aos concorrentes, através da multiplicidade de soluções com foco na qualidade.

Com uma equipe multidisciplinar, composta por profissionais de diferentes setores de atuação, foi comentada a necessidade de ter um volume de serviços que fidelizem estes profissionais à GSeabra, onde se procura constantemente alternativas de diferentes caminhos, um deles é a divulgação por meio de plataformas digitais.

Assim, uma das necessidades identificadas é a falta de capital suficiente para realizar a compra de novas ferramentas, como estas plataformas, com o intuito de reduzir o prazo de entrega dos serviços a serem contratados. Outros pontos seriam a aplicação de treinamento intensivo aos seus colaboradores e a utilização de software para divulgação das atividades da empresa.

Mesmo a organização disponibilizando uma variedade de serviços, o Sr. Guilherme acredita que ainda existem outros conteúdos que podem ser agregados aos seus clientes. Para ele, existem diversas atividades no empreendimento do consumidor que necessitam de melhoria, entretanto devem ser priorizados os que apresentem maior rentabilidade à sobrevivência da GSeabra.

Uma busca constante neste segmento é identificar o tipo de prestação de serviço que possibilite um contrato de longo prazo com o cliente. 
Outro tópico abordado foi o uso da promoção de seus serviços. Para isso ele assegurou que neste tipo de atividade não se pratica a promoção de produtos adotada, por exemplo, em lojas ou supermercados, pois isso reduziria de forma drástica a qualidade oferecida, impactando uma solução eficiente, que comprometeria os resultados esperados pelos consumidores da GSeabra. Assim, o cliente tem que reconhecer que o serviço entregue com qualidade é um investimento e não uma despesa para o seu empreendimento.

$\mathrm{Na}$ questão de aplicação de marketing para alcançar o seu cliente final, o Sr. Guilherme busca constantemente aumentar o seu portfólio de consumidores através das oportunidades de visitas a feiras de exposições e inclusive para participar como expositor em eventos voltados ao seu segmento. A participação desses eventos ainda não é o que se deseja. Estas feiras não são frequentes, pois algumas acontecem a cada dois anos, tempo suficiente para os clientes em potencial esqueçam do último contato com a empresa.

Com a finalidade de disponibilizar aos consumidores um produto de rápida implementação, preservando a qualidade, a GSeabra pretende criar um "Kit Marketing”, com o objetivo de oferecer serviços bem definidos ao abordar novos contratantes.

Quando questionado sobre os integrantes da empresa, o seu fundador informou que os chama de colaboradores, pois eles não são funcionários e sim microempreendedores, donos de seus próprios negócios, que compartilham a mesma visão e valores junto com a GSeabra.

É importante que todos os colaboradores assimilem o processo de desenvolvimento da imagem da GSeabra, uma vez que estão envolvidos nos projetos contratados. Devendo seguir a metodologia padronizada pelo empreendimento base deste estudo, pois os serviços, acabam se repetindo em projetos futuros. A padronização, torna-se essencial para se conseguir agilizar as atividades, objetivando resultados eficientes com um menor esforço e criando assim espaço para melhorias constantes.

Ainda de acordo com Sr. Guilherme, os colaboradores observando os resultados e o surgimento de novos projetos, ficam mais motivados, ao perceberem a possibilidade de crescimento em sua remuneração.

Hoje, o treinamento dos colaboradores ocorre apenas entre um projeto ou outro, ou antes do início de um serviço de maior porte. Na visão do sócio-fundador, este treinamento deveria ocorrer de forma sistemática, mesmo para os projetos de menor porte e de curto prazo, já que estes são os que mais surgem na GSeabra.

Para o Sr. Guilherme, o que valoriza a empresa é conseguir a integração de uma equipe multidisciplinar na área de engenharia que se complementa, e a ênfase na Segurança, 
através da ferramenta de análise de riscos. Esta abordagem não só antecipa a visualização de um eventual dano, como também oferece uma garantia de proteção ao negócio.

$\mathrm{Na}$ fase atual, acredita que seu maior desafio é formar uma equipe técnica com habilidades em vendas, para que estes possam trazer serviços através de seus contatos individuais.

$\mathrm{Na}$ visão futura da GSeabra em um prazo de 5 anos, o Sr. Guilherme espera que sua participação seja exclusivamente como gestor e conselheiro para a direção dos negócios, não precisando atuar diretamente nas tarefas do dia a dia. Com isso terá mais tempo para observar, analisar e investir na procura de novas oportunidades.

\subsection{Entrevista com colaboradores}

Neste tópico, serão abordadas as entrevistas com dois colaboradores, através de perguntas específicas, mas estavam livres para se pronunciarem sobre qualquer tema que presumissem ser desafiadores para a empresa.

As entrevistas ocorreram no dia 01 de novembro de 2019 entre $10 \mathrm{~h}$ e $14 \mathrm{~h}$.

\subsubsection{Entrevista com Aloísio Fernandes Cardoso}

Aloísio tem 34 anos e é formado em Engenharia Elétrica.

Antes de ser colaborador da empresa, o entrevistado trabalhou em cinco outras empresas. Com estes conhecimentos, o sócio-fundador interessou-se por suas habilidades profissionais e o contratou para prestar serviços de apoio em informática à GSeabra. A sua formação em Engenharia Elétrica e a facilidade em lidar com projetos permitiram a sua inclusão em alguns serviços, demonstrando desenvoltura na realização das tarefas e alinhamento as desafios da GSeabra.

De acordo com o entrevistado, sua primeira percepção na GSeabra foi positiva, pois a considerou uma empresa com qualidade, apesar de pequena, com visão moderna nas relações de contratação e pela forma dinâmica de conduzir os trabalhos. Com isso, ele vislumbrou a oportunidade de participar em todas as etapas dos projetos como um microempreendedor. Pela sua visão, a empresa preza pela qualidade dos serviços prestados.

Quando foi questionado sobre os concorrentes da GSeabra, afirmou que a concorrência não oferece a mesma qualidade do serviço fornecido. Informou que o 
conhecimento diversificado, a qualidade técnica e a imparcialidade são fatores que fazem a empresa se diferenciar no mercado.

O maior desafio da GSeabra é manter um fluxo de trabalho constante. O Sr. Aloísio acredita que no futuro a organização cresça de forma sustentável, que é um objetivo no qual a empresa já está focada. Ressaltou que o conhecimento técnico e a qualidade aplicada são os pontos fortes da GSeabra. Na sua percepção o ponto fraco é a capacidade interna limitada de atender rapidamente a grandes volumes de serviços, o que ocorre eventualmente.

Sr. Aloisio concorda com as ações de otimização dos tempos gastos nas execuções dos serviços e, assim, conseguir um maior controle e eficiência, porém alguns projetos não permitem essa diminuição na duração, por se tratarem de influências externas geradas pelos clientes.

$\mathrm{Na}$ sua percepção, uma melhoria que poderia tornar a empresa mais eficiente seria estruturar uma equipe de vendas e diversificar produtos e atividades. Afirma ainda que a falta de estruturação de uma equipe de vendas é o ponto fraco da empresa. $\mathrm{O}$ entrevistado também declarou que se sente bem no ambiente de trabalho e que tem liberdade para apresentar suas ideias.

Em relação ao preço, o Sr. Aloísio considera que o valor cobrado está na média do mercado. Sobre as ações de marketing, considera que são boas. Em relação aos clientes, ele considera que estes ficam satisfeitos com o serviço prestado. Algumas vezes desejam um serviço grande e complexo, porém no momento da contratação tentam amenizar a complexidade, para que o valor final fique o menor possível. Em relação a críticas e situações de desconforto com os clientes, estas ocorrem quando a empresa aponta erros de segurança do trabalho nos processos destes ou correções para atender às normas regulamentadoras.

Para ele, o motivo de os clientes buscarem a GSeabra é por conta das referências positivas e indicações de outras empresas. Sobre oportunidades e riscos relativos ao negócio da empresa, ele diz não conseguir identificá-los neste momento.

A sua visão para a empresa daqui a cinco anos é: "Com a mesma visão moderna na contratação dos colaboradores e com mais Associados e pela equipe de vendas estruturada, maior volume de trabalho". 


\subsubsection{Entrevista com Leonardo Dei Ricci}

O Sr. Leonardo tem 37 anos e está em fase de finalização do curso de Engenharia Mecânica. Ele conta que começou a trabalhar na GSeabra através da indicação de um amigo em comum ao sócio-fundador. Comenta que quando chegou na organização, sua primeira percepção foi de seriedade e qualidade na forma de trabalho com os clientes, fator que o atraiu para fazer parte da equipe. Gostou também do bom ambiente no dia a dia, fazendo com que ele se sentisse com liberdade para dar sugestões. Para ele, a empresa está inserida no mercado de forma diferenciada pela qualidade técnica apresentada e pela capacidade de enfrentar dificuldades.

Para o entrevistado, os clientes buscam a GSeabra por conta de sua credibilidade no mercado. Ele também comenta que a empresa pratica um preço "honesto". Considera que o empreendimento está bem localizado no Rio de Janeiro pelo fácil acesso.

Segundo o Sr. Leonardo, a empresa tem pontos para melhorias. De acordo com ele, a deficiência está na falta de uma estratégia de marketing que explore ferramentas que usem a internet como canal de comunicação. Como ponto forte, destaca o marketing pessoal, ou seja, o networking do fundador, contudo acredita que uma boa estratégia de marketing deve ser mais abrangente. Ele destaca a falta de investimentos no marketing digital da GSeabra, o que seria uma forma de captar novos clientes e serviços.

O maior desafio da empresa para o Sr. Leonardo é a falta de tempo para atender a prazos reduzidos e quando aumenta o volume de trabalho na GSeabra, a mesma não pode atender em curto prazo, isso possibilita a transferência de serviços aos seus concorrentes.

A sua visão para a empresa daqui a 5 anos é que se torne uma referência no mercado e conquiste um "selo" de qualidade tão almejado pelo fundador. Uma marca que seria fornecida pela GSeabra para garantir o reconhecimento e a confiabilidade dos serviços realizados em seus empreendimentos e para os equipamentos adquiridos pelos clientes.

\subsection{Observação dos clientes}

Com o intuito de compreender um pouco mais o perfil dos clientes que contratam os serviços da GSeabra e os motivos que os levam a escolher essa empresa para a realização de serviços, foi realizada uma pesquisa de observação dos mesmos, em função da pandemia. 
$\mathrm{Na}$ pesquisa foram utilizados registros tais como: e-mails, propostas, contrato, atas de reuniões, documentos encaminhados, fotos e cronogramas.

A pesquisa foi realizada, no período de 18 de abril de 2020 a 20 de maio de 2020, buscando as impressões dos clientes perante o preço, praça, promoção, produto, processo, ambiente físico e pessoas.

\subsection{Cliente 1- Fábrica de Lubrificantes}

Este cliente é uma fábrica que produz óleos automotivos e dentro da sua planta industrial possui diferentes setores. Na produção é necessário combinar os óleos com os aditivos. São utilizados diferentes equipamentos e existem esteiras transportadoras que transferem internamente os produtos até o setor de encaixotamento para o transporte, para serem encaminhados aos seus distribuidores.

Para a pesquisa de observação, foram utilizados e-mails, propostas, atas de reuniões, documentos encaminhados e cronogramas.

\subsubsection{Produto / Serviços}

A origem do trabalho surgiu para que a GSeabra (GS) atendesse a uma exigência legal onde foi necessário executar serviços de engenharia de Projetos e de Segurança.

O cliente foi auditado pelo Ministério do Trabalho, que notificou a apresentação de documentos e treinamentos de seus funcionários em 60 dias a partir da data da fiscalização.

O objetivo da contratação da GS foi desenvolver o inventário de máquinas com análise de risco exigidos pelo órgão fiscalizador, que estão relacionadas com a NR-12 (Segurança no Trabalho em Máquinas e Equipamentos).

Uma vez que esta norma regulamentadora possui vários níveis de exigências, o ponto de partida é o inventário dos equipamentos, seguido da aplicação da análise de risco a cada um dos equipamentos, que inclui a necessidade de treinamento dos operadores de máquinas.

$\mathrm{O}$ primeiro contato do cliente foi telefônico, seguido de visita da GS à fábrica e o restante do processo de comunicação até o fechamento da proposta entre as partes foi realizado por meio de e-mails, discutindo o que deveria ser feito no prazo de 60 dias. Após o 
fechamento da prestação de serviço, foram realizadas reuniões presenciais com a GS e colaboradores, todas documentas em atas registrando as etapas acordadas entre as partes com as responsabilidades de cada um na prestação da consultoria e no levantamento de dados necessários.

\subsubsection{Preço}

Este $\mathrm{P}$ foi o mais discutido pelas partes, por conta da divergência no entendimento do escopo a ser realizado.

Como não ocorreu previamente um roteiro bem definido, e houve várias trocas de email de negociação, os itens de execução e o valor final da proposta não ficaram claros entre as partes.

Durante a execução do projeto, o cliente incluiu mais serviços do que o combinado inicialmente, com isso a GS recebeu ao final um valor menor do que o esperado.

Ocorreram trocas de e-mails da GS com o cliente detalhando o valor cobrado, contudo este não concordou com a quantia final apresentada, pois ainda achava o preço elevado, por considerar que possuía boa parte do material que seria aproveitado na entrega à fiscalização.

Por não haver um contrato assinado antes do início dos trabalhos, os valores ficaram em aberto, na maior parte do tempo de execução do trabalho, devido à urgência de atendimento aos prazos.

A situação da falta de uma proposta formalizada e um contrato assinado neste trabalho mostra a fragilidade da GS por não ter documentos padronizados para situações emergenciais, tal como o ocorrido neste serviço.

Outro ponto vulnerável da GS foi assumir um problema do cliente sem garantia de contrato e de receber pelo trabalho executado. Caso ocorresse algum problema com o cliente, como por exemplo, não ter a verba suficiente para o pagamento, a GS e seus colaboradores ficariam com o prejuízo. Isso se tornou mais crítico, pois além do preço inicial não ter sido formalizado, outras demandas foram acrescidas, aumentando o risco de prejuízo.

Nas demandas seguintes, todas relativas a fiscalização do MTE, o cliente solicitou descontos, atendidos pela GS após rodadas de negociação, através de troca de e-mails, não existindo mais uma vez documento legal (contrato) comprovando que cliente iria garantir o pagamento. 


\subsubsection{Praça}

Podemos observar que a fábrica do cliente onde o serviço foi executado é de difícil acesso e longe do escritório da GSeabra. Isso, seria mais uma variável que deveria ter sido considerada no preço e na garantia final por meio de um contrato.

O difícil acesso gerou dificuldades de transporte para os colaboradores da GS, provocando custos individuais ressarcidos pela GS, além do maior tempo dispendido por cada um, pois individualmente escolheram o seu próprio meio de deslocamento. Poderia ter sido feito um planejamento melhor para a locomoção, através de contratação alternativa de transporte.

Caso a GS tivesse contratado colaboradores que morassem mais perto do cliente ou se tivesse parcerias com outras empresas mais próximas, os gastos seriam menores e consequentemente os lucros maiores. Essa possibilidade, por falta de um planejamento prévio, não foi considerada na formação do preço.

\subsubsection{Promoção}

O cliente chegou à GS por indicação de networking, pois é o segmento de trabalho onde o sócio-fundador atuou enquanto empregado, antes de abrir o seu próprio empreendimento.

Outras empresas foram contatadas pelo cliente. A base de conhecimento no segmento de lubrificantes foi decisória para a contratação da GS.

A empresa está muito dependente dos relacionamentos de networking, limitando a sua expansão.

\subsubsection{Pessoas}

Neste cliente houve a participação de quatro colaboradores da GS: um engenheiro de segurança, um administrador, um desenhista e o próprio sócio- fundador da empresa, que é engenheiro mecânico. 
Para a realização da atividade, foi opção da GS dividir as visitas em duplas de colaboradores, que se alternavam nas idas à fábrica, para poderem dessa forma realizar serviços para outros clientes, uma vez que não possuem exclusividade com a GS.

Entre as trocas de e-mails, ocorreram alguns problemas de comunicação. Por exemplo, enquanto o sócio-fundador solicitava certos documentos, o desenhista que estava em visita ao local comentou com os supervisores da fábrica que aqueles documentos não seriam úteis para a realização da planta baixa. Trazendo mais um item a ser administrado internamente, por ter sido questionado pelo cliente, demandando bastante do sócio-fundador neste projeto.

Durante o trabalho, percebe-se pelas trocas de e-mails, que outras ocorrências de repasse de informações pelos colaboradores da GS geraram dúvidas ao cliente, ocasionando a necessidade de atuação no local do sócio-fundador.

Os exemplos acima, demonstram a necessidade de treinamento prévio aos seus colaboradores, para melhorar a comunicação com o cliente.

Também podemos observar nos documentos apresentados sobre o serviço, que faltou um detalhamento melhor entre o contratado e o contratante da atividade que seria executada, pois o responsável pela fábrica cobrou da GSeabra um escopo diferente na visão da GS e ainda solicitou o envio de relatórios mais simples para os seus funcionários e acréscimo de informações.

No treinamento interno para os colaboradores, deve ser levado em conta o uso de palavras-chave, como otimizar e viabilizar, a aplicação de metodologias pré-definidas, como reuniões após cada visita ao cliente, scripts de argumentação para ajudar os colaboradores no momento de repassar os serviços da GSeabra e uma atuação no pós-venda.

\subsubsection{Ambiente Físico}

Este $\mathrm{P}$ não será utilizado para observação, visto que todos os contatos foram nas instalações do cliente, pelo tipo de serviços que foi executado. Assim, foram utilizados emails, atas, relatórios, entre outros e a empresa contratada não mostra sua opinião sobre o ambiente que o empreendimento base deste estudo se localiza.

\subsubsection{Processo}


A GS foi contratada pelo cliente para atendimento a uma notificação da fiscalização do ministério do trabalho, o que implicou um prazo reduzido que deveria ser cumprido sob o risco do cliente ter as suas instalações fechadas. Foi necessário executar serviços vinculados a engenharia de Projeto e conceitos da Engenharia de Segurança.

No começo, os contratantes da fábrica de lubrificantes queriam que o serviço fosse realizado em apenas 30 dias, porém, após esclarecimentos ao cliente quanto à complexidade dos trabalhos, os mesmos concordaram em executar em 60 dias, que era o prazo estipulado pelo fiscal do MTE.

Com isso, os colaboradores tiveram que aumentar a carga horária de trabalho.

A consultoria da GS, consistiu no levantamento do inventário, plantas de locação de equipamentos dos setores, manuais dos fabricantes das máquinas, listagem dos equipamentos dos setores indicados e elaboração de um plano de manutenção de cada máquina e treinamento com capacitação de todos os operadores.

Foram utilizados no desenvolvimento do trabalho:

a) Planilha eletrônica com o levantamento do inventário (dados das máquinas)

b) Formulários de apreciação de risco para cada tipo de máquina

c) Medidas de proteção; organização em pasta dos documentos disponíveis da empresa contratante para o prontuário;

d) Mapa com pontuação de avaliação a ser demonstrado através de uma matriz de risco para cada máquina e planta baixa de localização das máquinas e indicação dos seus pontos do sistema de segurança.

Ao longo do trabalho a GS encontrou dificuldades em reunir os dados necessários para a finalização do projeto, pois no entendimento do cliente alguns dos seus documentos já estariam prontos e poderiam ser aproveitados, reduzindo o prazo de entrega.

$\mathrm{Na}$ apresentação parcial do trabalho surgiram várias dúvidas por parte dos funcionários que executariam as melhorias do maquinário. Estavam confusos no entendimento e em que parte da máquina deveria ser mexido. A partir disso, a GS reestruturou novos relatórios com fotos e uma melhor formatação para a leitura, para facilitar o entendimento aos novos sistemas de segurança em cada uma das máquinas analisadas.

No final do projeto acordado inicialmente, o cliente acrescentou para a GS mais um item, que foi ministrar treinamento aos funcionários da fábrica, para o atendimento a 
notificação do Ministério do Trabalho. Assim, foi montado um curso específico para essa necessidade de capacitação.

Quadro 1 Avaliação do Processo pela visão da GSeabra comparado ao do cliente

\begin{tabular}{|c|c|c|}
\hline Item & Visão da GS sobre o serviço & Visão do Cliente sobre o serviço \\
\hline $\begin{array}{l}\text { O Pedido do cliente é de fácil } \\
\text { execução ? }\end{array}$ & $\begin{array}{l}\text { Não - A notificação faz referência } \\
\text { à totalidade da NR12 }\end{array}$ & $\begin{array}{l}\text { Sim - Pois a notificação só } \\
\text { especificou dois itens. }\end{array}$ \\
\hline $\begin{array}{l}\text { A execução será atendida no } \\
\text { prazo com facilidade? }\end{array}$ & $\begin{array}{l}\text { Não - Pois é conhecedor do } \\
\text { assunto }\end{array}$ & $\begin{array}{l}\text { Em parte }- \text { Pois acha que tem } \\
\text { muitos documentos que possam ser } \\
\text { aproveitados }\end{array}$ \\
\hline Conhece o risco envolvido? & Sim - Pois pode fechar a fábrica & Sim - Pois pode fechar a fábrica \\
\hline Conhece a norma? & Sim - Tem pleno conhecimento & Em parte - De forma reduzida \\
\hline $\begin{array}{l}\text { Possui dados suficientes para } \\
\text { o início do trabalho? }\end{array}$ & $\begin{array}{l}\text { Não - Pois pela experiência da GS, } \\
\text { os dados sempre precisam de } \\
\text { atualização }\end{array}$ & $\begin{array}{l}\text { Sim - Acha que tem todos os } \\
\text { documentos atualizados }\end{array}$ \\
\hline $\begin{array}{l}\text { O material final entregue foi } \\
\text { de fácil entendimento? }\end{array}$ & $\begin{array}{l}\text { Sim- Estavam bem detalhados } \mathrm{e} \\
\text { obedecendo a norma }\end{array}$ & $\begin{array}{l}\text { Não - Nem todos os funcionários } \\
\text { possuem conhecimento da norma }\end{array}$ \\
\hline $\begin{array}{l}\text { Necessidade de } \\
\text { serviços }\end{array}$ & $\begin{array}{l}\text { Sim - Devido ao item treinamento } \\
\text { que a notificação exigiu }\end{array}$ & $\begin{array}{l}\text { Não - Primeiro momento achavam } \\
\text { que podiam fazer o treinamento } \\
\text { com alguém interno. }\end{array}$ \\
\hline $\begin{array}{l}\text { Todos os materiais estavam } \\
\text { na língua portuguesa? }\end{array}$ & Sim & Não \\
\hline
\end{tabular}

Fonte: elaborado pelo autor

Neste $\mathrm{P}$, verifica-se que a percepção da contratante e da contratada eram distintas em alguns pontos. Também ocorreu uma certa demora para conseguir todos os materiais necessários para a realização das atividades da GS.

Houve diversas trocas de e-mails com a solicitação de arquivos, mas com o cliente inicialmente em dúvida se poderia disponibilizar os mesmos por serem confidenciais e no idioma inglês.

A princípio a opção do cliente era receber o material da GS e depois acrescentar o material corporativo direto para entrega para a fiscalização, para a redução de custo envolvido na contratação da GS. Contudo, em função da dificuldade em consolidar todo o material, a tradução do seu conteúdo, no prazo reduzido, o cliente acabou adicionado esse item ao trabalho. 
A insistência da GS em obter todas as informações disponíveis ao longo do trabalho gerou um certo incômodo ao cliente, que acabou concordando em disponibilizar o material para o atendimento aos prazos do Ministério de Trabalho.

O projeto atendeu ao objetivo em que foi contratado, pois a fábrica do cliente, após a auditoria do órgão fiscalizador, continuou em sua atividade normal por ter atendido às exigências apontadas.

Apesar dos pontos a melhorar na GS, como a falta de propostas padronizadas e problemas de comunicação, houve um reconhecimento do cliente para os trabalhos futuros.

\subsection{Cliente 2 - Hospital}

Este cliente é um hospital que pertence a uma rede hospitalar em fase de expansão de suas instalações, construindo um novo prédio em anexo ao já existente. Todo hospital possui sistemas de geração de energia para uso emergencial no caso de falta de energia e para este novo prédio também foi necessário a instalação de equipamentos chamados de geradores elétricos. Esses geradores funcionam a óleo diesel, sendo necessário possuir um ponto de alimentação para este combustível, que recebe o óleo por meio de um caminhão-tanque e é conduzido através de tubulações até o gerador.

Para a pesquisa de observação foram utilizados e-mails, propostas, atas de reuniões, documentos encaminhados, cronogramas e slides.

\subsubsection{Produto / Serviços}

A origem do trabalho surgiu para que a Gseabra (GS) realizasse um trajeto da tubulação de óleo diesel aos geradores considerando as análises de risco na implantação da tubulação. Em resumo, a GS foi contratada pelo cliente para elaborar um projeto de instalação, análise de risco, melhorias e soluções de engenharia.

O primeiro contato do hospital com a GS foi através de telefone seguido de uma visita nas instalações do cliente. O processo de comunicação até o fechamento da proposta foi realizado por meio de e-mails discutindo as ações do que deveria ser feito. Após a fase de negociação dos serviços e valores, foi assinada uma carta de intenção (pré-contrato).

$\mathrm{Na}$ execução dos serviços foram realizadas reuniões presenciais com o sócio fundador da GS e seus colaboradores, todas documentadas em atas, para registro do que foi acordado 
entre as partes, definindo as responsabilidades de cada um na prestação dos serviços e no levantamento dos dados necessários.

A prestação de serviço da GS foi calcular a bomba a ser utilizada e definir o melhor trajeto da tubulação de diesel, que tinha que percorrer vários andares do hospital até chegar a cobertura do prédio, onde ficam os geradores elétricos a serem abastecidos.

Após o projeto ser aprovado pelo cliente, as obras foram iniciadas pelo hospital, que não estavam sob a supervisão da GS. O cliente contratou um empreiteiro para a construção do sistema diesel. Contudo, o mesmo não seguiu à risca o projeto elaborado pelo empreendimento base deste estudo.

Isso foi constatado no andamento da obra por um dos engenheiros do cliente, que percebeu que as etapas do projeto da GSeabra não estavam sendo cumpridos integralmente, surgindo uma oportunidade de nova contratação da GS para supervisionar a execução do trabalho do empreiteiro na instalação da tubulação.

Após a entrega do serviço pela GS, o cliente contratou um empreiteiro para executar o projeto, porém esta atividade começou a ter problemas, pois o empreiteiro não obedecia ao que foi desenhado e por não ter um engenheiro que soubesse fiscalizar o trabalho, o hospital voltou a fazer contato com o empreendimento base deste estudo para uma nova contratação, direcionada à supervisão do trabalho executado pelo empreiteiro.

Vale ressaltar que os serviços prestados pela GS foram diferentes. Não tendo relação do primeiro com o segundo serviço.

O primeiro contrato foi para executar o projeto do trajeto de tubulação e o cálculo da bomba e o segundo foi para a fiscalização da execução. Esta segunda contratação ocorreu da mesma forma que a primeira, por e-mails, atas de reuniões, contratos, cronogramas, e visitas técnicas.

O projeto final do sistema diesel foi adicionado com novas plantas que serviram para a legalização, além do combinado em proposta comercial, e assim poderia ser usado pelo cliente para atender a outras finalidades, tais como: aprovação do Corpo de Bombeiros e exigências da Secretaria do Meio Ambiente.

Com isso a GS gastou mais tempo estimado inicialmente, cedendo às solicitações do cliente, entregando desenhos que não estavam incluídos na proposta, sem custo para o contratante, visando a um reconhecimento futuro destas complementações para outras contratações, porém gerando custos internos para a GS. 


\subsubsection{Preço}

Este $\mathrm{P}$ teve vários impasses no início da negociação, por conta do valor da proposta da GS. Isso ocorreu porque o cliente achou que o preço estava muito elevado para o trabalho a ser feito. Na visão dele seria apenas uma adequação a um projeto antigo, já existente de outra empresa contratada, sem considerar a análise de risco que seria aplicada.

Com isso a GS teve que justificar de forma detalhada os itens da contratação, apresentando outras propostas similares a este serviço para outros hospitais da mesma rede.

Mesmo assim, ocorreram novos questionamentos pelo cliente e a GS foi pressionada a aplicar um desconto para fechar a proposta.

A mesma situação repetiu-se na segunda contratação sobre o valor proposto pelo empreendimento base deste estudo na supervisão da obra. Porém ocorreu uma falha da GS que estimou o tempo de execução acompanhando a estimativa do empreiteiro, mas o tempo de obra foi o dobro, reduzindo a rentabilidade prevista, uma vez que a GS teve um gasto a mais de tempo e de despesas de deslocamento para este período maior.

Este P mostra a necessidade da GS se preparar melhor no levantamento dos custos para os serviços mais complexos, listando antecipadamente os diferentes cenários e assim ter mais argumentos na negociação, para evitar gastos imprevistos e/ou produtos a mais entregues ao cliente sem cobrar por isso.

\subsubsection{Praça}

Neste P, foi observada a dificuldade de acesso ao hospital, não só pela distância da sede da GS como também pelo congestionamento enfrentado para chegar ao local, não conseguindo ter a rapidez desejada pelo cliente quando convocado para ir à obra de forma emergencial.

Na segunda contratação, para fiscalização, isso ocorreu diversas vezes, pois cada ida não programada do sócio-fundador à obra, prejudicava o atendimento de outros clientes, além deste custo não ter sido previsto na proposta inicial. 
Uma forma de minimizar esta dificuldade e melhor atender o cliente, seria estabelecer um dos colaboradores como responsável pelo atendimento emergencial, de preferência com residência próximo à obra.

\subsubsection{Promoção}

A GS foi indicada pelos próprios engenheiros da obra, pois conheciam o seu trabalho de projetos similares realizados em outras unidades da Rede Hospitalar.

O histórico do sócio-fundador da GS no ramo de combustíveis ajudou na indicação, porém um ponto mais forte ainda foram os projetos já realizados em outros hospitais da rede.

O networking da GS é importante, mas para a sua expansão é necessário desenvolver outros canais de promoção, utilizando os serviços já prestados.

\subsubsection{Pessoas}

Neste cliente, a GS utilizou quatro profissionais: um projetista, um técnico de edificações, um engenheiro de segurança e o próprio sócio-fundador, que é engenheiro mecânico. Uma vez que se tratava de uma grande obra, a equipe do hospital era formada por engenheiros de diferentes áreas, contratos, civil, elétrica e estrutural, assim, em algumas das reuniões havia até dez funcionários do cliente. Com esse quantitativo de pessoas, as reuniões se tornavam mais longas devido aos questionamentos de cada área e consequentemente os registros em atas tornavam-se também mais trabalhosos em função de todos os assuntos acordados.

Para a realização dos serviços, os colaboradores foram ao cliente em diferentes momentos, revezando-se para tirar dúvidas tanto na execução do projeto como na fiscalização da instalação da tubulação.

Todos os pontos observados por cada um nas visitas eram repassados ao sóciofundador, que centralizou todas as informações, o que, além de gerar sobrecarga de trabalho, não agilizou o compartilhamento das informações entre os colaboradores da GS neste projeto, perdendo rapidez nas ações.

A GS poderia ter indicado um determinado colaborador para cada etapa, como o projetista na gestão nas modificações construtivas que apareceram na obra, outro para tratar 
das análises das situações de risco encontradas e o terceiro que morasse mais próximo à obra para um atendimento emergencial com a rapidez desejada pelo cliente.

Estas ações poderiam ter reduzido a sobrecarga de trabalho direcionada ao sócio-fundador e reduzido o seu tempo dedicado a este cliente. Essa situação foi agravada no segundo serviço aplicado na obra, a inspeção do empreiteiro, pois reduziu a velocidade de chegada à obra nas situações emergenciais, já que algumas vezes ele estava em outros clientes, não podendo atender de imediato.

Outra dificuldade encontrada neste $\mathrm{P}$ foi a forma de comunicação entre a equipe da GS e a equipe do hospital, no momento das visitas realizadas. Os colaboradores da GSeabra explicavam de forma muito técnica as alterações pretendidas na parte mecânica, sendo que em algumas visitas, o engenheiro que os recebia na obra não dominava os termos técnicos, por não ser da área mecânica.

Isso demonstra a falta de treinamento da equipe da GS na forma de apresentar os problemas encontrados na obra, especialmente pelo fato de precisar interagir com tantos profissionais de diferentes áreas, exigindo um tempo maior nos esclarecimentos passados ao cliente.

\subsubsection{Ambiente Físico}

Este P não será utilizado para observação, visto que todas as visitas e reuniões foram realizadas nas instalações do cliente em função dos serviços executados. Além dos contatos presenciais, as demais comunicações foram realizadas por meio de e-mails, atas, relatórios e em nenhum momento o cliente sentiu necessidade de ir ao escritório da GS.

\subsubsection{Processo}

O Hospital em fase de expansão de suas instalações contratou a GS para realizar um projeto de tubulação de óleo diesel para alcançar os geradores elétricos localizados na cobertura do prédio, sendo necessário aplicar análises de risco na execução, devido à passagem da tubulação por todos os andares do prédio. Todo hospital possui geradores de 
energia para uso emergencial, para no caso de falta de energia serem acionados automaticamente.

A contratação da GS aconteceu em dois momentos distintos: a primeira contratação foi para executar o projeto de funcionamento do gerador e a segunda para fiscalizar a execução da obra, que foi realizada por um empreiteiro contratado diretamente pelo cliente. A primeira contratação envolveu as seguintes etapas:

a) estudo de análise de risco para as diferentes posições do tanque de armazenagem no interior da edificação;

b) melhor percurso da tubulação em toda a extensão até a cobertura do prédio;

c) melhor posicionamento da bomba e o correto dimensionamento;

d) estudo de área de riscos de explosão e incêndio.

Diante da complexidade do projeto, o cliente envolveu vários setores da construção para avaliar as interferências de suas áreas de responsabilidade elétrica, estrutural e civil. Com isso este serviço exigiu da GS uma interação constante com diversos setores do cliente, todos com o mesmo objetivo de evitar alterações nas suas áreas de atuação que já estavam construídas.

Isso justifica os diversos questionamentos dos engenheiros por parte do cliente nas reuniões que ocorreram, sendo gastas muitas horas de discussão e de registros das atas.

$\mathrm{Na}$ execução do serviço ocorreram várias reuniões com a finalidade de esclarecer cada ponto no projeto, onde o sócio-fundador sempre estava presente com um dos colaboradores da GS.

Com este tipo de cenário, a GS deveria ter combinado antecipadamente com o cliente que o coordenador da obra estivesse presente em todas a reuniões para dar a palavra final nas discussões mais prolongadas.

Para minimizar o tempo gasto nas reuniões, sócio-fundador deveria ter preparado uma segunda pessoa da equipe que estivesse alinhada com todos os assuntos, para que sua presença não fosse obrigatória em todas as reuniões.

Outro ponto identificado é fortalecer a gestão administrativa no escritório, desde o fechamento da proposta e ao longo da execução, pois foi necessário o envio de vários documentos a pedido do cliente. A falta desse apoio administrativo resultou em retrabalhos, como, por exemplo, reencaminhar a proposta, já que o primeiro documento enviado estava sem o CNPJ e a identificação do cliente no cabeçalho. 
A segunda contratação da GS foi devido aos engenheiros do cliente terem percebido que a obra não estava sendo executada conforme as especificações do projeto. A GS foi contratada então para fiscalizar a obra executada pelo empreiteiro da contratante, para garantir a correta execução com foco na segurança. A segunda contratação envolveu as seguintes etapas:

a) vistoria das instalações do trajeto das tubulações já iniciadas pelo empreiteiro contratado pelo cliente;

b) conferência dos materiais a serem utilizados com o projeto inicial da GS;

c) aprovação das alterações ocorridas na execução;

Nesta segunda contratação foi utilizada a mesma equipe de colaboradores que atuou no primeiro serviço contratado. Este novo trabalho continuou a envolver os vários setores do hospital, exigindo uma comunicação ainda mais constante, pois a obra estava em plena execução.

Na elaboração desta proposta, o empreendimento base deste estudo baseou-se no cronograma estabelecido pelo empreiteiro da contratante com as etapas e a data para conclusão da obra, contudo este cronograma não foi cumprido pelo terceirizado do cliente, prejudicando os trabalhos da GS. O atraso ocorreu porque o empreiteiro precisou refazer grande parte da instalação, como a troca de materiais, além disso demorou para apresentar as documentações necessárias para a comprovação da origem dos equipamentos especificados no projeto.

Pela urgência na contratação desta etapa, a GS não efetuou um maior aprofundamento sobre a situação prévia da obra. Isso refletiu diretamente na data da entrega final da construção e comprometeu o retorno financeiro do trabalho, uma vez que a proposta da GS não considerou a possibilidade de atraso por parte do empreiteiro, ou seja, foram necessários mais tempo e recursos que não estavam previstos inicialmente.

Faltou ao empreendimento base deste estudo provocar uma reunião prévia antes do início dos serviços, com a presença conjunta do empreiteiro e do cliente, para estabelecer as condições de fiscalização e andamento dos prazos.

A GS deveria ter colocado no contrato cláusulas de responsabilidade no caso de atraso, por conta de depender tanto de um terceiro. Outro ponto a ser destacado é que a GSeabra 
deveria ter formalizado um novo prazo, já sabendo que haveria o atraso por conta das falhas do empreiteiro.

Quadro 2 Avaliação do Processo pela visão da GSeabra comparada à do cliente

\begin{tabular}{|c|c|c|}
\hline Item & Visão da GS sobre o serviço & Visão do Cliente sobre o serviço \\
\hline $\begin{array}{lll}\text { Qualidade } & \text { do } & \text { Serviço } \\
\text { Executado ? } & & \\
\end{array}$ & $\begin{array}{l}\text { Bom- A GSeabra conseguiu } \\
\text { eliminar o problema }\end{array}$ & Bom - Atendeu às expectativas \\
\hline $\begin{array}{l}\text { Possuía dados suficientes para } \\
\text { o início do trabalho? }\end{array}$ & $\begin{array}{l}\text { Não }- \text { Faltaram dados } \\
\text { solicitados e houve demora na } \\
\text { entrega pelo cliente }\end{array}$ & $\begin{array}{l}\text { Sim - Forneceu todos os dados } \\
\text { disponíveis. }\end{array}$ \\
\hline O prazo foi atendido? & $\begin{array}{l}\text { Sim - No primeiro serviço de } \\
\text { projeto } \\
\text { Não - Para o serviço de } \\
\text { fiscalização em função do atraso } \\
\text { do empreiteiro }\end{array}$ & $\begin{array}{l}\text { Sim - No primeiro serviço de } \\
\text { projeto } \\
\text { Não - Para o serviço de } \\
\text { fiscalização, pois ultrapassou o } \\
\text { prazo. }\end{array}$ \\
\hline $\begin{array}{l}\text { GS conhece o serviço } \\
\text { contratado? }\end{array}$ & $\begin{array}{l}\text { Sim - Pela experiência anterior } \\
\text { com outros hospitais }\end{array}$ & $\begin{array}{l}\text { Não - Falta conhecimento dos } \\
\text { riscos gerados pelo óleo diesel }\end{array}$ \\
\hline $\begin{array}{l}\mathrm{O} \text { atendimento foi } \\
\text { satisfatório? }\end{array}$ & $\begin{array}{l}\text { Sim- A GS ficou disponível para } \\
\text { atendimento. }\end{array}$ & $\begin{array}{l}\text { Em parte- Em algumas vezes a } \\
\text { GS não pode atender de } \\
\text { imediato, ida à obra. }\end{array}$ \\
\hline $\begin{array}{l}\text { O material final entregue foi } \\
\text { de fácil entendimento? }\end{array}$ & $\begin{array}{l}\text { Sim }-\mathrm{O} \\
\text { autoexplicativo }\end{array}$ & $\begin{array}{l}\text { Sim - Reconhecido e respeitado } \\
\text { pelo cliente e que gerou um novo } \\
\text { serviço para GS }\end{array}$ \\
\hline $\begin{array}{lll}\begin{array}{l}\text { Necessidade } \\
\text { serviços }\end{array} & & \text { outros } \\
\end{array}$ & 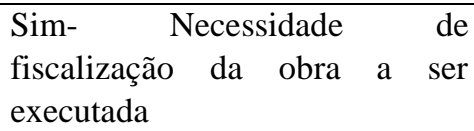 & $\begin{array}{l}\text { Sim - Depois dos erros } \\
\text { identificados na obra executada } \\
\text { pelo empreiteiro. }\end{array}$ \\
\hline
\end{tabular}

Fonte: elabor ado pelo autor este $\mathrm{P} \quad \mathrm{e}$ com base nesta

tabela, vemos que a percepção da contratante e da contratada eram distintas em alguns pontos. O cliente não tinha o conhecimento técnico dos riscos envolvidos pelo óleo diesel e achou que tinha fornecido todos os dados necessários para execução do trabalho.

As maiores dificuldades foram na segunda contratação, por conta da GS depender de terceiros, no caso o empreiteiro contratado pelo próprio cliente, que não cumpriu o cronograma apresentado. Assim, a GS deveria ter se aprofundado mais no reconhecimento da situação da obra no início dos serviços. 
Apesar das dificuldades encontradas, o projeto da GS atendeu ao objetivo pelo qual foi contratado, pois o hospital realizou a obra de instalação da tubulação de diesel para alimentar os geradores com sucesso.

Apesar dos pontos a melhorar na GS, houve um reconhecimento do cliente para futuros trabalhos, visto que após o término do primeiro trabalho, o cliente entrou em contato para a realização da segunda contratação para o gerenciamento de obra.

\subsection{Cliente 3 - Prédio Comercial}

Este cliente é uma empresa multinacional de São Paulo, que está sendo transferida para o Rio de Janeiro e para isso alugou um prédio comercial de 26 andares, todo com fachadas de vidro e dois heliportos, que possui ainda equipamentos instalados na cobertura, que também fazem parte de funcionamento do prédio.

Por se tratar de um edifício novo, que nunca havia sido ocupado antes, o cliente contratou a Gseabra (GS) para uma avaliação de análise de risco destes equipamentos instalados na cobertura, que são compostos por pórticos e gôndolas, utilizados na manutenção dos vidros e limpeza das fachadas.

Para a pesquisa de observação foram utilizados e-mails, propostas, atas de reuniões, documentos encaminhados e fotos.

\subsubsection{Produto / Serviços}

O edifício alugado pelo cliente possui equipamentos instalados na cobertura, compostos de pórticos e gôndolas, para acesso às fachadas de vidro dos seus 26 andares e assim efetuar a sua manutenção. O prédio pertence a uma construtora que tem como negócio construir para alugar.

O cliente, locatário, preocupado com a segurança desses equipamentos, queria saber se as instalações ao serem utilizadas, suportariam o peso das gôndolas, o peso dos funcionários e dos materiais que seriam utilizados na troca dos vidros, como também para a limpeza da fachada, sem trazer riscos aos funcionários do prédio que executariam essa atividade. Para melhor visualização, abaixo uma figura autoexplicativa do que se trata: 


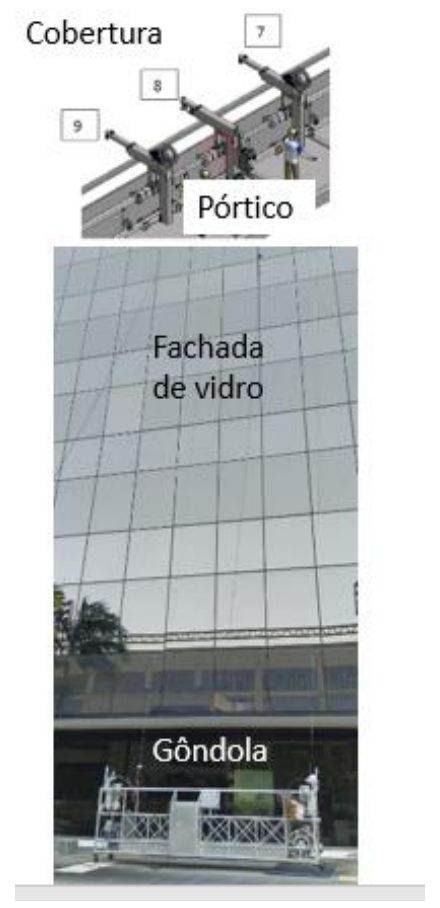

Figura 3 Fachada do prédio - equipamento - pórtico na cobertura e gôndola da manutenção

Antes de ocupar o prédio, o cliente queria ter certeza sobre a confiabilidade de uso desses equipamentos. Assim, entraram em contato com a GS para solicitar uma análise de riscos operacionais e de segurança relacionados às gôndolas e à instalação dos pórticos, além dos testes de carga nas próprias gôndolas.

$\mathrm{Na}$ realização deste serviço, a GS avaliou o funcionamento dos equipamentos e, ao final, aplicou o teste de carga para conferir se o sistema, pórticos e gôndolas realmente suportavam a carga máxima indicada pelo fabricante, garantindo a segurança na operação de limpeza, manutenção e troca de vidros.

O primeiro contato deu-se por telefone, seguido de trocas de e-mail. Como o cliente estava localizado em outro estado, foram realizadas videoconferências com o sócio-fundador da GS junto com a sua equipe, para esclarecimentos dos serviços a serem executados.

Após o fechamento da proposta, o cliente disponibilizou projetos e todas as demais informações julgadas essenciais sobre o sistema instalado, inclusive cedido pelo proprietário do prédio, o laudo estrutural do equipamento do fornecedor do pórtico.

A prestação de serviço da GS foi para entregar um parecer técnico sobre todos os pontos observados, a forma que foi instalado e como foi realizada a fabricação dos equipamentos, identificando pontos a serem melhorados e para garantir uma total segurança de uso. 
A partir da entrega do laudo técnico pela GS, o cliente exigiu do proprietário do prédio as providências de correção dos pórticos e das gôndolas, necessárias à segurança das operações de manutenção da fachada, isso tudo antes de sua entrada no prédio.

\subsubsection{Preço}

Neste $\mathrm{P}$ foram encontradas pela GS dificuldades similares de negociações já ocorridas com outros clientes, pois em geral, por falta de conhecimento técnico, eles supõem que o trabalho a ser executado é menos complexo do que é na realidade. Neste caso, a visão do setor de engenharia do cliente achava que o serviço a ser executado tratava-se somente de uma comprovação da normalidade de uso do equipamento, atestado por uma consultoria externa, que neste caso era a GS.

Com isso o empreendimento base deste estudo teve que antecipadamente detalhar todas as etapas que iriam ser aplicadas e mostrar a sua responsabilidade na emissão do laudo, compostos de análise de engenharia sobre o sistema (pórticos e gôndolas), para que houvesse a liberação de uso dos equipamentos.

Para garantir a segurança de liberação do equipamento foi incluído na proposta da GS a realização de um teste de carga, para o qual foi preciso a contratação de uma empresa terceirizada, para simular com pesos iguais aos das pessoas e materiais o que seria transportado nas gôndolas.

Assim, para a realização deste teste de carga, a GS contratou uma empresa terceirizada indicada pelo seu networking, especializada na fabricação de gôndolas, a qual possui profissionais capacitados para trabalho em altura e dispõe de pesos padrões, que foram aplicados nos testes. A contratação deste terceirizado feita pela GS a curto prazo, atendeu à urgência do cliente, para que permitisse o mais breve possível a sua transferência para o Rio de Janeiro para a ocupação do prédio.

A contratação urgente dessa empresa terceirizada sob a responsabilidade direta do empreendimento base deste estudo trouxe riscos financeiros desnecessários, pois a condição comercial desta empresa era receber de forma antecipada o valor total da contratação, ou seja, antes do início da execução do serviço. Com isso, o pagamento foi realizado de forma antecipada, assumindo riscos desnecessários, antes mesmo da GS receber a primeira parcela de pagamento do seu cliente. 
Esta situação poderia ter criado um prejuízo financeiro à GS, por ter feito antecipação de pagamento de terceiros e não receber do cliente ao final do trabalho. Apesar desta situação não ter ocorrido, fica caracterizado o risco.

Outro ponto frágil, pela urgência de contratação, é que não foi feito um contrato formalizado, sendo as negociações e aprovações de cada etapa dos serviços registradas apenas por meio de e-mail.

Isso mostra mais uma vez a necessidade da GS sempre aplicar contratos, mesmo que simplificados, junto a seus clientes ou terceiros que venha a contratar, antes do início de execução dos serviços, caso contrário sempre assumirá o risco de falha no entendimento entre as partes e do que foi negociado não ser cumprido. Neste trabalho, a formalização ocorreu somente sobre os registros em proposta e pelas trocas de e-mail.

Outro ponto também identificado é que a GS precisaria ter previsto na negociação um prazo maior com o cliente e, assim, ter tido mais tempo para procurar outras opções de terceirizados da mesma especialidade no mercado para não ficar na dependência de uma só empresa, tendo que aceitar as precondições de pagamento exigidas pelo terceirizado contratado. Apesar do risco, o valor em proposta da GS foi pago corretamente sobre o serviço acordado.

\subsubsection{Praça}

Na execução deste projeto este P mais uma vez não foi relevante, pois a localização do prédio a ser ocupado pelo cliente era de fácil acesso e próximo do escritório da GS, não envolvendo custos fora do esperado.

\subsubsection{Promoção}

O cliente chegou até a GS por meio de uma recomendação do seu próprio networking, pois a GS já havia feito um trabalho similar em uma empresa parceira do seu cliente.

Ajudou na contratação o histórico do sócio-fundador do empreendimento base deste estudo por atuar como perito judicial, pois o cliente precisava, além da especialidade da engenharia mecânica, de sua imparcialidade na análise sobre todos os aspectos de segurança envolvidos no funcionamento das gôndolas e pórticos, tais como: a correta construção dos 
equipamentos e de suas instalações e ter a segurança na operação, tudo isso por meio de um laudo com soluções de todos os aspectos avaliados.

Foi fundamental para o fechamento deste negócio a recomendação da empresa parceira do cliente e a particularidade do trabalho que já tinha sido executado em um dos seus networkings, fazendo com que o cliente não buscasse outras consultorias na concorrência.

\subsubsection{Pessoas}

Na prestação de serviços a este cliente, houve a participação de três engenheiros da equipe GS, todos com especialização na área de segurança industrial e apenas um com formação em engenharia mecânica, que era o próprio sócio-fundador.

O contratante solicitou ao dono do prédio a ser ocupado a participação de um dos seus arquitetos que acompanhou a construção do edifício, para apoiar os trabalhos de campo da GS, o qual passou todas as informações necessárias sobre o histórico da instalação dos pórticos e gôndolas.

Além dos funcionários do cliente e dos arquitetos que construíram o prédio, a GS também precisou interagir com mais três outros técnicos da empresa terceirizada que realizaram os testes de carga do equipamento, ou seja, a GS precisou interagir com diversos profissionais de diferentes empresas e todos ficaram diretamente sob o comando do sóciofundador do empreendimento base deste estudo.

Como já ocorreu na prestação de serviços a outros clientes, mais uma vez a participação da GS foi constante em todas as etapas, neste caso justificado pela sua formação profissional em mecânica, essencial nas análises mecânicas.

Faltou à GS que houvesse um outro engenheiro mecânico na sua equipe, assim, pode haver uma distribuição melhor das etapas do serviço, onde o dono proprietário pudesse estar com maior dedicação somente no final na consolidação do laudo.

Na realização desse trabalho, a equipe da GS precisou lidar com profissionais de diferentes empresas, pois além dos funcionários do cliente, houve interação com os funcionários da empresa proprietária do prédio e com os funcionários da terceirizada contratada pela GSeabra para os testes de carga.

Este tipo de situação exigiu muita habilidade interpessoal para garantir o entendimento de todos, a fim de deixar clara a entrada de cada um no momento certo, através de um cronograma e do registro que havia sido combinado, através de atas e e-mails, de forma a não 
comprometer a continuidade das ações e cumprir o cronograma combinado com o cliente, devido à urgência dele para ocupação do prédio.

A equipe da GS não possuía experiência em lidar com todas estas interações. Essa falta de experiência justificou a exigência da intervenção direta do sócio-fundador para coordenar as frentes de trabalho. Faltou um melhor planejamento da GS para antecipar esse tipo de situação e não deixar a centralização em uma só pessoa, podendo, por exemplo, ter escolhido um dos engenheiros da sua equipe como coordenador dos trabalhos de campo.

Assim, neste trabalho o sócio-fundador envolveu-se em todas as atividades executadas no serviço. Mesmo ele sendo a referência de contratações da GS, poderia ter compartilhado mais a condução do projeto com outro profissional de mesmo nível e de conhecimento da equipe de trabalho, para aumentar a sua disponibilidade de atendimento a outros clientes.

\subsubsection{Ambiente Físico}

Este P mais uma vez não será utilizado para observação, visto que todos as visitas e reuniões foram realizadas nas instalações do cliente, em função dos serviços executados. Além dos contatos presenciais no campo, as demais comunicações foram realizadas por meio de videoconferência, e-mails, atas, relatórios e em nenhum momento o cliente solicitou ida ao escritório da GS.

\subsubsection{Processo}

A GS foi contratada pelo cliente para uma avaliação da segurança dos pórticos e gôndolas utilizados para a manutenção da fachada do prédio para onde estavam de mudança, e assim, exigir as melhorias e providências necessárias ao proprietário do edifício.

Por se tratar da primeira ocupação do prédio, o cliente estava com receio de utilizar os equipamentos e haver algum acidente durante a operação, razão pela qual contratou a GS para uma análise de risco dos pórticos e gôndolas tanto na parte construtiva, como também no atendimento às normas regulamentadoras do Ministério do Trabalho e da ABNT (Associação Brasileira de Normas Técnicas).

A contratação da GS dividiu-se em duas etapas: a primeira foi avaliar se os equipamentos instalados estavam obedecendo às normas construtivas e de operação e uma 
segunda etapa para realizar um teste de carga para conferir a sustentação do peso máximo permitido pelos pórticos e gôndolas, sem risco.

1. Primeira etapa de serviços contratados:

Para realizar a primeira etapa, a GS solicitou toda a documentação necessária para uma análise preliminar, antes de ser efetuada a visita no campo:

a) plantas e documentos construtivos do prédio;

b) planta de localização dos equipamentos instalados;

c) simulação de diferentes cenários de risco na operação dos equipamentos;

d) avaliação da operação dos pórticos e gôndolas;

A partir da análise destes documentos, o empreendimento base deste estudo elaborou um planejamento e um cronograma de ações, que envolviam tanto os funcionários do cliente, como os do proprietário do prédio e os da empresa terceirizada contratada diretamente pela GS, que participaram das inspeções em dias alternados.

A GS precisou analisar nesta primeira etapa a forma como o equipamento foi fabricado, o modo como foi instalado e até a maneira correta de ser operado, o que exigiu uma análise de risco de cada variável separadamente, listando as necessidades de melhoria para cada uma delas.

Ao final desta etapa foi elaborada uma tabela detalhando o que foi analisado, os riscos identificados e apontadas as soluções de correção, o que permitiu ao contratante exigir do proprietário do prédio as devidas correções junto à empresa fornecedora dos pórticos e gôndolas, garantindo a segurança, já que seria o usuário das instalações.

2. Segunda etapa dos serviços contratados:

Estava incluído desde o início da contratação da GS a realização de testes de carga para comprovar se os pórticos suportariam os pesos nas gôndolas. Para isso foi necessário que a GSeabra contratasse uma empresa terceirizada do ramo de gôndolas para aplicar o teste prático da carga máxima informada pelo fabricante do equipamento, garantindo a segurança de operação ratificada pela GS.

Essa contratação urgente de empresa terceirizada sob a responsabilidade direta do empreendimento base deste estudo trouxe riscos financeiros desnecessários, pois a condição 
da empresa terceirizada era de receber de forma antecipada o valor total da contratação, antes do início da execução do serviço.

O risco foi identificado sobre vários pontos, sendo:

a) pagamento realizado ao terceirizado de forma antecipada, mesmo não sabendo se iria atender;

b) pagar o terceirizado antes da GS receber a primeira parcela de pagamento do cliente e

c) sem saber sobre a aceitação final do cliente após o trabalho finalizado.

Esta situação poderia ter criado um prejuízo financeiro à GS, por essa antecipação de pagamento, uma vez que todas as aprovações de cada etapa de todo serviço foram feitas por email, sem um contrato formalizado.

A contratação de uma empresa terceirizada de forma direta foi uma novidade nos processos em geral aplicados pela GS, pois nunca havia ocorrido uma necessidade dessas antes.

A novidade de contratação de uma empresa terceirizada, aliada à urgência do cliente em ocupar o prédio, fez com que o empreendimento base deste estudo aceitasse as condições comerciais da contratada. $\mathrm{O}$ fato dessa terceirizada ter sido recomendada por um parceiro da GS pelo bom trabalho executado em outra obra também pesou na decisão, principalmente pela falta de experiência anterior neste tipo de contratação.

Nesta segunda etapa de serviço acabou ocorrendo uma redução da margem de lucro da GS neste cliente. Colaboraram para isso a sua falta conhecimento das etapas de teste e, assim, não ter negociado melhor as condições de contratação da empresa terceirizada. Aumentando o tempo gasto para entendimento do processo de testes de carga e surgindo a necessidade de contratação de uma apólice de seguro para garantia em caso de um eventual acidente durante os testes, além de um aumento no custo de homem/hora estimado no planejamento do trabalho da equipe da GS no campo.

Em síntese, de todos os fatores listados acima, o que mais impactou na margem de lucro deste serviço, foi a inclusão do teste de carga, que exigiu mais tempo gasto do que foi orçado incialmente, gerando custos extras. Faltou à GS disponibilizar mais tempo na pesquisa de outras opções de terceirizadas no mercado com a mesma especialidade no ramo de gôndolas, que fosse mais lucrativa à empresa base deste estudo.

Essa experiência de contratação feita pela GS deve ser analisada e melhorada para futuras necessidades, para que a empresa não fique sujeita à mesma situação. 
Quadro 3 Avaliação do Processo pela visão da GSeabra comparada à do cliente

\begin{tabular}{|c|c|c|}
\hline Item & Visão da GS sobre o serviço & Visão do Cliente sobre o serviço \\
\hline $\begin{array}{l}\text { O Pedido do cliente é de fácil } \\
\text { execução? }\end{array}$ & $\begin{array}{l}\text { Não - Pois envolveu a contratação } \\
\text { de uma empresa terceirizada sob } \\
\text { responsabilidade da GS }\end{array}$ & $\begin{array}{l}\text { Sim - Pois a contratante foi bem } \\
\text { explícita na sua necessidade e } \\
\text { como queria que fosse feito. }\end{array}$ \\
\hline $\begin{array}{l}\text { A execução será atendida no } \\
\text { prazo com facilidade? }\end{array}$ & $\begin{array}{l}\text { Em parte - Pois a primeira parte } \\
\text { dependia diretamente da GS, } \\
\text { enquanto que a segunda etapa que } \\
\text { envolveu o teste de carga } \\
\text { dependeria } \\
\text { terceirizada. }\end{array}$ & $\begin{array}{l}\text { Sim- Eles só queriam uma } \\
\text { comprovação de que } \text { de } \\
\text { equipamento poderia ser usado de } \\
\text { forma segura. }\end{array}$ \\
\hline Conhece o risco envolvido? & $\begin{array}{l}\text { Sim - Pois a GS é conhecedora de } \\
\text { máquinas e normas }\end{array}$ & $\begin{array}{l}\text { Em parte - Apesar de saber sobre o } \\
\text { risco, o interesse é saber se o } \\
\text { equipamento podia ser usado. }\end{array}$ \\
\hline Conhece a norma? & $\begin{array}{l}\text { Em parte - Na primeira etapa a } \\
\text { empresa tem pleno conhecimento, } \\
\text { porém na segunda dependia de } \\
\text { uma terceirizada }\end{array}$ & $\begin{array}{l}\text { Não- Desconhecia as normas } \\
\text { regulamentadoras e as normas de } \\
\text { testes de cargas }\end{array}$ \\
\hline $\begin{array}{l}\text { Possui dados suficientes para } \\
\text { o início do trabalho? }\end{array}$ & Sim-Foram solicitados ao cliente & $\begin{array}{l}\text { Sim - Tinha todos os documentos } \\
\text { atualizados }\end{array}$ \\
\hline $\begin{array}{l}\text { O material final entregue foi } \\
\text { de fácil entendimento? }\end{array}$ & $\begin{array}{l}\text { Sim- Estavam bem detalhados e } \\
\text { organizados }\end{array}$ & $\begin{array}{l}\text { Em parte }- \text { Nem todos que } \\
\text { receberam o laudo tinham } \\
\text { formação técnica. }\end{array}$ \\
\hline $\begin{array}{lll}\text { Necessidade } & \text { de } & \text { outros } \\
\text { serviços } & & \end{array}$ & Não & Não \\
\hline $\begin{array}{l}\text { A terceirização da empresa do } \\
\text { teste de cargas foi } \\
\text { preocupante? }\end{array}$ & $\begin{array}{l}\text { Sim - Pois a GSeabra não possuía } \\
\text { experiência neste assunto, assim } \\
\text { não sabia como fazer as } \\
\text { solicitações e como escolher a } \\
\text { empresa }\end{array}$ & $\begin{array}{l}\text { Não- Pois a responsabilidade da } \\
\text { contratação e da eficiência da } \\
\text { terceirizada foi toda da GSeabra }\end{array}$ \\
\hline
\end{tabular}

Fonte: elaborado pelo autor

Por conta da falta de experiência na contratação de terceirizados, a GS desconhecia que precisaria informar tantos dados técnicos necessários à realização dos testes de carga, o que impactou a velocidade das informações, fazendo a GS ter mais trabalho que o esperado. 
Outro ponto que merece atenção é a formulação dos contratos, incluindo cláusulas que aumentem a quantia final, caso o cliente necessite de mais dados do que informado inicialmente ou apresente novas demandas, que impliquem aumento de tempo de serviço ao empreendimento tal como base deste estudo.

Também podemos observar que o sócio-fundador iniciou o serviço para este cliente sem a aceitação formal da proposta, sendo algo essencial nesse ramo, onde somente a formalização do valor é algo válido no meio judicial para o recebimento da quantia, ainda mais em se tratando de um novo cliente, onde não há um histórico de relacionamento comercial.

Por fim, identifica-se a necessidade da criação pela GS de uma padronização com o passo a passo para a contratação de empresas terceirizadas, assim como é já é feito para a execução dos serviços nos clientes, ajustando inicialmente o valor das atividades e o que ela proverá para a GS, pois esse foi o ponto com que o empreendimento base deste estudo teve mais dificuldades de lidar, tendo assim dificuldade de repassar o valor final da terceirizada para o cliente final. Como consequência, teve sua margem de lucro reduzida ao perder tanto tempo para as trocas de informações.

Outra sugestão, é que quando laudos técnicos forem direcionados a profissionais sem formação em engenharia, como aconteceu neste caso, a GS faça uma apresentação em formato fotográfico, com imagens ou fluxogramas, para que o contratante possa usar internamente, facilitando o esclarecimento sobre os problemas apontados.

\subsection{Cliente 4 - Fábrica de Graxa}

O cliente em questão é uma fábrica que produz graxas automotivas. Possui vários andares dentro de suas instalações e em cada andar é realizada uma etapa da produção, sendo no pavimento térreo gerado o produto final, que é a graxa.

Os riscos nestas atividades são inúmeros, pois são utilizados equipamentos quentes, cortantes e pesados. Qualquer erro no maquinário ou na forma de utilizá-los trará prejuízos à saúde dos empregados, até com risco de vida. As condições do ambiente de trabalho chamaram a atenção do Ministério do Trabalho, que notificou o cliente quanto a melhorias necessárias para preservar a saúde do trabalhador.

Para a pesquisa de observação foram utilizados e-mails, propostas, atas de reuniões, documentos encaminhados e cronogramas. 


\subsubsection{Produto / Serviços}

A fiscalização nas instalações da fábrica identificou irregularidades, gerando uma notificação para o cumprimento das exigências até uma data estabelecida pelo próprio Ministério do Trabalho.

Daí a necessidade da contratação da Gseabra (GS) para desenvolver o inventário de máquinas com análise de riscos exigida pelo órgão fiscalizador, que estão relacionados com a NR-12 (Segurança no Trabalho em Máquinas e Equipamentos). Uma vez que esta norma regulamentadora possui vários níveis de exigências, o ponto de partida é o inventário dos equipamentos, seguido da aplicação da análise de risco a cada um deles.

A fábrica de graxas precisou identificar o nível de segurança dos equipamentos nos pontos considerados perigosos com base em normas da Associação Brasileira de Normas Técnicas (ABNT).

O primeiro contato do cliente com a GS foi por telefone e após a visita foram formalizados por e-mail o descritivo dos serviços e o valor a ser pago. Após o aceite da proposta, a GS iniciou as atividades, conforme cronograma apresentado em proposta.

Os produtos oferecidos ao cliente foram:

1- aplicar uma tabela indicando os problemas dos principais equipamentos,

2- reconhecer os riscos com mapeamento dos setores de cada ambiente,

3- apresentar um laudo técnico do diagnóstico de risco por meio de fotos.

Com base na experiência anterior com outros clientes da GS do mesmo segmento, os serviços foram realizados sem dificuldade.

\subsubsection{Preço}

Durante a abordagem deste $\mathrm{P}$ não houve dificuldades, pois, o contratante não contestou o valor cobrado pela GS, por ter sido notificado pelo Ministério do Trabalho com prazo de cumprimento das exigências, então a agilidade em elaborar os documentos necessários era essencial.

Também é relevante destacar que o valor negociado foi feito presencialmente direto com o sócio-fundador, que conseguiu repassar com clareza o motivo do valor da proposta, 
onde foram incluídas todas as despesas envolvidas para o serviço, tais como taxa de urgência, contratação de projetistas para fazer a planta da fábrica, transporte para locomoção até a fábrica e alimentação, entre outros.

A forma de pagamento foi realizada após a entrega de cada uma das etapas dos serviços, uma vez que não ocorreu um contrato formalizado.

Apesar de existir uma proposta formalizada, não houve um contrato assinado e nem um sinal de pagamento antes do início do trabalho, ou seja, a GS correu o risco de o cliente não cumprir o acordado e justificar o não pagamento, caso o serviço não atendesse às suas expectativas, antes de receber o serviço concluído.

Isso mostra um fator de vulnerabilidade do empreendimento base deste estudo, o de não receber sobre o valor total do trabalho que foi apresentado em proposta, ou seja, em receber somente pelas etapas realizadas, já que o cliente não tinha obrigação formal de cumprir o acordado em relação ao valor final da proposta.

\subsubsection{Praça}

Na execução desta consultoria este $\mathrm{P}$ não teve relevância, pois, apesar da fábrica ser distante do escritório da GS, a mesma acordou com o cliente, que os valores de deslocamento fossem repassados no custo final da proposta.

Com isso, não houve impactos financeiros negativos para este serviço, pois esse tema foi acordado de forma antecipada.

O único entrave significativo foi a distância da fábrica para o escritório da GS, que implicou mais tempo do que o previsto na locomoção.

\subsubsection{Promoção}

O cliente chegou até a GS por meio de uma recomendação do gerente da fábrica em questão, que conhecia o sócio-fundador, por terem trabalhados juntos em outra empresa.

A contratação da consultoria foi facilitada devido à similaridade de segmento e do tipo de serviço a ser executado, semelhante ao da empresa onde atuaram juntos. Assim, sabendo do histórico e da qualificação do sócio-fundador, o gerente da fábrica não teve dificuldades na 
escolha do empreendimento base deste estudo. Vemos mais um serviço sendo realizado por conta do Networking.

A partir dos resultados satisfatórios nesta primeira unidade fabril, o cliente solicitou que a GS executasse o mesmo trabalho em outra unidade fabril.

Esta situação demonstra à GS que este tipo de serviço pode ser frequente, devido às fiscalizações constantes do Ministério do Trabalho nesta atividade de fabricação de óleo e graxas, podendo ser uma oportunidade de transformar um produto a ser oferecido a empresas similares que atuam neste mesmo setor.

\subsubsection{Pessoas}

Neste cliente, a GS utilizou três integrantes na equipe de trabalho: um engenheiro ambiental e de segurança, um engenheiro mecânico e de segurança, além do próprio sóciofundador, formado em engenharia mecânica. Os colaboradores foram distribuídos pelas funções que seriam realizadas. Na divisão, um engenheiro da equipe ficou responsável pela análise de riscos das máquinas e o outro pelo levantamento de dados.

Neste trabalho, a equipe da GS trabalhou de forma autônoma, sem depender de autorizações por parte do cliente nas etapas que foram realizadas, pois existiu liberdade de acesso a todos os setores que estavam sendo avaliados. Isso facilitou a realização do serviço pela GS, que conseguiu se organizar de forma mais eficiente e mais produtiva.

Neste serviço, sócio-fundador não precisou estar envolvido em todas as etapas, pois cada um dos engenheiros já possuía as devidas qualificações necessárias.

Outro aspecto que facilitou o andamento do trabalho, foi o fato de o responsável pela contratação da GS ser engenheiro e conseguia entender com desenvoltura o que seria realizado no serviço. Assim, os integrantes da GS não tiveram perda de tempo para explicar os pontos que estavam sendo identificados.

O empreendimento base deste estudo deveria, dentro do possível, contar com colaboradores com o mesmo nível de experiência do sócio-fundador para a distribuição de tarefas. Neste trabalho foi possível a inclusão de profissionais experientes e de maiores custos,

pois o cliente aceitou o valor da proposta sem pedir redução, devido à urgência e complexidade do assunto para atender à notificação do Ministério do Trabalho. 


\subsubsection{Ambiente Físico}

Como todas as visitas e contatos ocorreram nas instalações do cliente, em função dos serviços executados, este P não foi utilizado para a observação.

\subsubsection{Processo}

A fábrica entrou em contato com a GS por conta de uma notificação da fiscalização do Ministério do Trabalho sobre a NR-12, que é a norma que regulamenta sobre as operações de máquina de forma segura e que avalia os hábitos preventivos e eventuais situações de perigo e emergências.

Se esta norma não fosse cumprida até a próxima visita da fiscalização, o contratante teria suas instalações fechadas, sendo fundamental a realização de serviços vinculados à engenharia de projeto em máquinas e conceitos da engenharia de segurança.

A confiabilidade de contratação da GS e a liberdade de ações dentro da unidade fabril favoreceu o andamento dos serviços e o término dentro do prazo programado.

A consultoria da GS consistiu em desenvolver um quadro autoexplicativo mostrando os problemas em cada um dos equipamentos, identificando os riscos operacionais em cada ambiente da fábrica e, ao final, apresentou um laudo técnico dos riscos envolvidos por meio de fotos, com medidas propostas para o melhoramento do maquinário.

As visitas nas unidades do cliente foram bem espaçadas e distribuídas pela a equipe na elaboração dos trabalhos, onde o sócio-fundador do empreendimento base deste estudo esteve nas instalações do cliente para o reconhecimento do local, identificando o que seria feito, e no final para a apresentação do trabalho realizado.

Após a visita de campo e o entendimento por parte dos integrantes da GS sobre quais os problemas de risco das máquinas e como elas afetariam os trabalhadores, ocorreu a quarta e última visita presencial, com a participação de todos os envolvidos da GS no projeto, ou seja, os dois colaboradores e o sócio-fundador.

Na reunião de conclusão dos trabalhos, todos da equipe do empreendimento base deste estudo participaram para apresentar o diagnóstico final, com as objeções encontradas em cada maquinário e os pontos que deveriam ser corrigidos para atender às normas regulamentadoras.

Neste $\mathrm{P}$ foi observado que situações já ocorridas em outros clientes repetiram-se neste trabalho, como a não realização de um contrato formalizado, trazendo riscos desnecessários 
para a GS, caso não ocorresse o pagamento. A empresa base deste estudo necessita formalizar a proposta em contrato, não importando se o cliente é confiável ou se já realizou parte do pagamento adiantado. Este registro, além de ser um fator judicial imprescindível, também é a confirmação de que o serviço foi executado.

Devido à GS ser uma empresa de pequeno porte, é relevante tornar o contrato essencial, pois no caso de uma recusa de pagamento, haverá prejuízos financeiros, que dependendo do valor envolvido, poderão não ser recuperados, impactando a sobrevivência da empresa.

Quadro 4 Avaliação do Processo pela visão da GSeabra comparada à do cliente

\begin{tabular}{|c|c|c|}
\hline Item & Visão da GS sobre o produto & Visão do Cliente sobre o produto \\
\hline $\begin{array}{l}\text { O Pedido do cliente é de fácil } \\
\text { execução? }\end{array}$ & $\begin{array}{l}\text { Sim - Pois a equipe da GS tem a } \\
\text { especialidade do assunto }\end{array}$ & $\begin{array}{l}\text { Não - Pois não sabia a extensão do } \\
\text { problema. }\end{array}$ \\
\hline $\begin{array}{l}\text { A execução será atendida no } \\
\text { prazo com facilidade? }\end{array}$ & $\begin{array}{l}\text { Sim - Pois o serviço era de pleno } \\
\text { conhecimento. }\end{array}$ & $\begin{array}{l}\text { Sim }- \text { Pela necessidade de } \\
\text { atendimento da notificação }\end{array}$ \\
\hline Conhece o risco envolvido? & $\begin{array}{l}\text { Sim - Possibilidade de fechamento } \\
\text { da fábrica }\end{array}$ & $\begin{array}{l}\text { Sim }- \text { Possibilidade de } \\
\text { fechamento da fábrica }\end{array}$ \\
\hline Conhece a norma? & Sim - Tem pleno conhecimento & $\begin{array}{l}\text { Em parte - Pois o contratante } \\
\text { conhecia a norma, sem a } \\
\text { profundidade necessária. }\end{array}$ \\
\hline $\begin{array}{l}\text { Possui dados suficientes para } \\
\text { o início do trabalho? }\end{array}$ & $\begin{array}{l}\text { Sim - Pois só dependiam da visita } \\
\text { no campo. }\end{array}$ & $\begin{array}{l}\text { Sim - Pois a contratação foi } \\
\text { aplicada para vistoriar os locais e } \\
\text { com livre acesso. }\end{array}$ \\
\hline $\begin{array}{l}\text { O material final entregue foi } \\
\text { de fácil entendimento? }\end{array}$ & $\begin{array}{l}\text { Sim- Estavam bem detalhados e } \\
\text { obedecendo a norma }\end{array}$ & $\begin{array}{l}\text { Sim- O contratante conseguiu ter o } \\
\text { entendimento dos riscos e } \\
\text { melhorias a serem feitas. }\end{array}$ \\
\hline $\begin{array}{lll}\text { Necessidade } & \text { de } & \text { outros } \\
\text { serviços } & & \\
\end{array}$ & $\begin{array}{l}\text { Sim - O cliente possuía uma outra } \\
\text { fábrica que se encontrava na } \\
\text { mesma situação. }\end{array}$ & $\begin{array}{l}\text { Sim - Já era de seu conhecimento } \\
\text { a situação da outra unidade fabril. }\end{array}$ \\
\hline $\begin{array}{l}\text { Melhor alocação dos } \\
\text { colaboradores da GSeabra? }\end{array}$ & $\begin{array}{l}\text { Sim- Pois todos os integrantes } \\
\text { participaram igualmente das } \\
\text { atividades, sem ter uma sobrecarga } \\
\text { de funções para cada um. }\end{array}$ & $\begin{array}{l}\text { A contratante não percebeu como } \\
\text { foram alocados os colaboradores }\end{array}$ \\
\hline
\end{tabular}

Fonte: elaborado pelo autor 
Neste P vemos que a percepção da GS e do cliente eram bem parecidas. O cliente disponibilizou acesso da equipe da GS à fábrica e com liberdade de entrevistas aos operadores das máquinas, trazendo informações com rapidez e de forma detalhada para o entendimento das necessidades de melhorias de segurança no maquinário.

O projeto atendeu de forma eficiente o objetivo final da contratação, pois o cliente solicitou um novo serviço ao empreendimento base deste estudo em outra unidade fabril, para a realização das mesmas atividades.

Neste cliente não ocorreram troca excessiva de e-mail e reuniões para esclarecimentos, reduzindo a quantidade de atas e, consequentemente, otimizando o tempo dispendido pela equipe GS para estas atividades.

\subsection{Cliente 5 - Fábrica de Celulose}

Este cliente é uma fábrica de celulose que produz papel para revistas e jornais, localizada no interior do Paraná, e que possui em sua planta industrial diferentes setores que compõem a sua linha de produção.

Os equipamentos da linha de produção da fábrica utilizavam óleo diesel como combustível e o cliente queria fazer a sua substituição por gás natural, ou seja, teria que desativar os tanques de óleo diesel e instalar vários cilindros de gás natural.

Como existiam tubulações ao longo da fábrica que levavam o combustível a cada um dos equipamentos, a preocupação do cliente era saber se poderia haver risco de explosão a partir da troca de sistema de óleo diesel para gás natural.

O contratante necessitava de uma auditoria no sistema de produção para validar os controles de segurança das suas operações, através da inspeção no novo sistema, que passaria para gás natural, identificando eventuais deficiências e apresentando melhorias para garantir a segurança das operações das máquinas e dos seus operadores.

Para a pesquisa de observação foram utilizados e-mails, propostas, contrato, atas de reuniões, documentos encaminhados e cronogramas.

\subsubsection{Produto / Serviços}


A origem do serviço da Gseabra (GS) ocorreu por conta da mudança de combustível de óleo diesel para o gás natural, sendo necessário executar serviços de engenharia de projetos e de segurança.

O objetivo da contratação foi realizar uma auditoria nas dependências da fábrica para gerar um relatório técnico, com diagnóstico preventivo dos riscos e operação do gás natural e garantir o funcionamento do sistema com segurança. O sistema de gás já estava instalado, aguardando um parecer final para liberação do início da operação.

Os contatos foram mantidos através de telefone e e-mails. A GS ofereceu ao contratante outro meio de comunicação, como videoconferência, mas eles não tinham os recursos necessários de fácil disponibilidade.

O produto contratado pelo cliente foi a inspeção do sistema de gases para identificar eventuais deficiências e indicar melhorias dentro da uma visão sistêmica da unidade de produção. Para conduzir esse trabalho era necessário que o profissional tivesse a formação em engenharia de segurança aliada à formação da engenharia mecânica e ainda dispor de expertise em projetos de gás natural.

Assim, o produto entregue ao cliente foi composto pelo relatório descritivo com parecer crítico a partir das ações abaixo:

a) verificar a validade documental;

b) identificar as responsabilidades técnicas;

c) avaliar as estratégias de respostas no plano de ação emergencial

d) conferir a descrição sucinta da sistemática operacional;

e) definir indicadores na operação à integridade e segurança do sistema

f) elaborar relatório fotográfico dos pontos identificados no descritivo

Vemos assim que o produto final foi apresentado através de dois relatórios para facilitar a compreensão do cliente.

Uma vez que o cliente não possuía o conhecimento específico sobre o assunto, foi elaborado também um fluxograma que demonstrasse o entendimento sobre a metodologia que seria aplicada no serviço a ser realizado. 
Após o entendimento final entre as partes sobre o serviço a ser realizado nas instalações do cliente foi necessário listar previamente todas as documentações indispensáveis para a realização da inspeção.

A condição imposta pelo sócio-fundador para ida à fábrica do cliente, em função da sua localização, foi que no dia da visita, todas as informações e todas as pessoas envolvidas no processo de transformação do óleo diesel pelo gás natural deveriam estar disponíveis. A parte documental estar à disposição era muito importante, pois caso os registros solicitados não fossem apresentados, a GS não poderia continuar a sua consultoria, conforme havia sido avisado ao cliente pela GS, antes do agendamento da visita.

O produto entregue ao cliente ao final do trabalho foram relatórios contendo os principais pontos para a garantia da segurança e funcionamento dos equipamentos, informando se era seguro realizar a troca pretendida, se haveria riscos nas instalações e aos trabalhadores e se os equipamentos adquiridos pelo cliente estavam em conformidade as normas da ABNT (Associação Brasileira de Normas Técnicas).

Os relatórios também incluíram a avaliação da capacidade técnica da empresa contratada pelo cliente para executar a obra e a conferência das documentações de compra dos novos equipamentos, incluindo os certificados de qualidade dos componentes, que garantem a segurança para os equipamentos.

\subsubsection{Preço}

Este $\mathrm{P}$, apesar de não ter gerado discussões sobre o montante cobrado, foi o que apresentou mais riscos para o empreendimento base deste estudo. $\mathrm{O}$ valor proposto foi aceito pelo cliente sem questionamento, devido à expertise da GS no assunto, contudo a visita às instalações do cliente fora do RJ foi feita pelo sócio-fundador sem a certeza de que o trabalho poderia ser de fato aplicado de forma completa, uma vez que a realização do serviço dependia de todos os documentos estarem disponibilizados no dia da inspeção, o que seria constatado apenas na hora da chegada à fábrica. Assim sendo, só haveria pagamento se o trabalho fosse realizado.

O conhecimento do sócio fundador sobre o assunto que seria analisado e o fato de o cliente ser uma empresa de grande porte, trazendo marketing positivo para a empresa, levou a GS em aceitar o trabalho, mesmo com o risco financeiro envolvido, já que as despesas de deslocamento e do tempo dedicado a esta empreitada poderiam não ser pagos. 
A proposta entregue contemplava os custos de deslocamento, porém na condição de receber na entrega do serviço realizado.

Assim, existia a ameaça financeira, assumida pelo sócio-fundador de que ao chegar no local e não ser possível completar o serviço, caso as documentações e pessoas solicitadas não estivessem disponíveis, ter que arcar com os prejuízos das despesas de deslocamento e hospedagem, além do tempo investido.

Porém, chegando ao local todos os documentos solicitados pelo empreendimento base deste estudo foram apresentados, podendo assim realizar o serviço por completo. A vistoria foi realizada dentro do prazo estimado e o prejuízo que poderia ter havido não ocorreu, pois, o cliente, ao receber o trabalho, efetuou o pagamento.

É valido ressaltar que ocorreu a elaboração de um contrato, mas somente após a inspeção ao contratante, devido à morosidade do seu setor jurídico. Inicialmente, houve aceitação da proposta por e-mail, que não é algo tão formalizado quanto a existência de um contrato. Este ponto é um erro cometido pela GS nos serviços oferecidos, já que a ausência ou a postergação da apresentação de um contrato é necessária para garantir o recebimento monetário e respalda a comprovação a entrega do serviço.

Também podemos chamar a atenção para o fato de a GS ter falhado em não acordar com o cliente uma pré-condição para ressarcimento de pelo menos as despesas de locomoção e hospedagem, caso o serviço não fosse realizado pela falta da documentação solicitada. Recomenda-se que nas próximas negociações a GS obtenha um compromisso formalizado junto ao cliente para o ressarcimento obrigatório das despesas de hospedagem e considerar as distâncias percorridas para os seus custos envolvidos.

\subsubsection{Praça}

As instalações do cliente ficam localizadas no interior do Sul do Brasil, a $300 \mathrm{~km}$ de distância da capital (Curitiba), sendo necessário que o sócio-fundador se deslocasse de avião até a capital do estado e de lá pegasse um carro para chegar à fábrica.

A grande distância entre a sede da GS e o local da fábrica foi levada em consideração quando a GS apresentou os valores a serem cobrados, nos quais estavam contemplados na proposta tanto para o transporte (passagem de avião, aluguel de carro e combustível) como para a hospedagem (hotel). 
Sendo válido ressaltar que o agendamento da visita foi feito com no mínimo 20 dias de antecedência para permitir a compra das passagens aéreas e atender ao orçamento programado.

Assim, este $\mathrm{P}$ não teve relevância neste caso, pois mesmo com o tempo gasto de locomoção, este fator foi remunerado e, apesar do risco financeiro envolvido na negociação, a GS não teve prejuízo com a ida ao local, já que o serviço foi executado e pago dentro do prazo estipulado.

\subsubsection{Promoção}

Ao contrário dos outros clientes esta fábrica não chegou à GS por meio de recomendação de outro cliente ou parceiro.

O consumidor entrou em contato com o empreendimento base deste estudo por conta de o sócio-fundador participar de um grupo de trabalho de revisão das normas da ABNT que envolvem o gás natural, pois eles buscavam um profissional com expertise para realização da inspeção da troca de combustível nas instalações da fábrica.

Vemos pela primeira vez um serviço da GS acontecer não por causa de indicação, mas sim por participação em eventos externos, cujas normas estão diretamente relacionadas à atuação profissional da GS.

\subsubsection{Pessoas}

Neste serviço, houve a participação de somente um integrante da GS, que foi a do próprio sócio-fundador, formado em engenharia mecânica, com especialização em engenharia de segurança. Devido à distância da fábrica, caso algum colaborador da GS residente no RJ o acompanhasse, os custos seriam maiores e os riscos financeiros também, já que não havia a certeza de que o serviço seria de fato executado.

Para evitar imprevistos e poder planejar a visita, a GS pediu ao cliente um detalhamento dos pontos a serem analisados na inspeção, para não ser surpreendido com outras demandas ao chegar lá. Após as partes chegarem a um acordo sobre o detalhamento do serviço a ser executado, o empreendimento base deste estudo elaborou um escopo do que seria entregue ao cliente. 
Ciente da necessidade de ter mais um colaborador no projeto a GS contratou um engenheiro autônomo para ajudá-lo no serviço, residente na região Sul do país, que havia trabalhado com o sócio-fundador na empresa na qual ambos atuaram por muitos anos. $\mathrm{O}$ custo de homem/hora deste engenheiro colaborador estava incluso na proposta inicial, não trazendo prejuízos pela sua contratação.

A função deste colaborador no projeto seria de apoio, tanto na locomoção e principalmente na coleta de informações e captura de fotos dos equipamentos a serem avaliados, dando mais liberdade para o sócio-fundador averiguar os pontos mais relevantes.

Na proposta inicial a GS comunicou que seria necessário o fornecimento de todas as documentações listadas e apoio dos profissionais da empresa para a facilitação da elaboração do serviço, garantindo a confidencialidade dos dados.

Atendendo ao solicitado, o cliente deixou a disposição da GS trinta funcionários da fábrica. Os empregados atuavam nas áreas industrial, engenharia de projeto, manutenção, segurança e administrativa, o que facilitou o desenvolvimento do serviço.

Com os pré-requisitos atendidos pelo cliente, a visita técnica conseguiu ser cumprida corretamente no prazo estipulado. Sendo válido ressaltar que neste P não houve dificuldades na execução do trabalho.

\subsubsection{Ambiente Físico}

Como a fábrica fica localizada em outro estado, os contatos para a aceitação do serviço ocorreram somente por telefone e por e-mail, não tendo vídeo chamada.

Com isso, vemos que este P não foi utilizado para observação.

\subsubsection{Processo}

A GS foi contratada pelo cliente por conta da mudança de combustível, de óleo diesel para o gás natural. Com isso, ocorreria uma troca de equipamentos, como tanque para o cilindro, além de outras substituições que teriam que ser realizadas.

A GS exemplificou como seria feito o serviço, colocando em tópicos as funções, que seriam: 
a. validar o projeto - conformidade com as normas atuais;

b. analisar riscos das instalações - elaborar um mapa do ambiente industrial com os produtos inflamáveis e mostrar a presença de mistura explosiva neste ambiente e sua extensão;

c. validar procedimentos de operação, intertravamentos e manutenção - revisar o manual;

d. avaliar soluções e procedimentos para controlar riscos - aplicar ferramentas de análise de risco;

e. elaborar laudo final atestando a conformidade da instalação e operação do sistema com o fornecimento de Anotação de Responsabilidade Técnica (ART) para a certificação do projeto adotado.

O cliente entrou em contato primeiro por telefone e em seguida formalizou a solicitação do serviço por e-mail. Visto que o sócio-fundador do empreendimento base deste estudo participava do grupo de trabalho de revisão das normas da ABNT, o contratante o considerou como um especialista em combustível e requisitou um laudo de avaliação de segurança pela substituição do óleo diesel para o gás natural.

O prazo da atividade, de acordo com a proposta aceita pelo cliente, deu-se pelo agendamento prévio para a definição da data das inspeções na instalação, ou seja, no mínimo com vinte dias de antecedência para permitir a compra das passagens aéreas e atender ao orçamento programado.

Em função da distância da fábrica, localizada no interior do Sul do país, o sócio-fundador detalhou as condições para a realização do serviço e como seria feito esse trabalho. Acordou de forma antecipada que ficaria apenas um dia na fábrica, já que precisaria de dois dias somente com o deslocamento. O cliente ficou receoso do curto prazo para a realização de todas as atividades, assim a GS encaminhou um e-mail detalhando todos os registros que seriam indispensáveis e alertou que não poderia faltar nada, pois caso algum documento não fosse apresentado, a GS não iria realizar o trabalho de forma completa.

Esta possibilidade era um fator de risco, pois a GS somente saberia se o serviço realmente seria feito quando chegasse ao local requerido. Caso faltasse algum documento, a empresa base deste estudo iria embora sem receber nada e todas as despesas gastas com transporte, refeição e com a contratação de um terceiro não seriam reembolsadas. Este risco é alto para o empreendimento, pois a empresa é de pequeno porte. Contudo, em termos de 
expansão de mercado, o risco compensava pelo potencial de novos clientes a partir deste trabalho.

Como o cliente atendeu a toda a documentação solicitada, o serviço pode ser realizado dentro do tempo esperado pela GS sem prejuízos financeiros, ampliando o portfólio de clientes fora do estado do RJ.

Um fator negativo neste cliente foi a formular o contrato somente após o encerramento das atividades, ou seja, antes de iniciar o serviço. A GS não possuía um comprovante legal, além dos e-mails, que validassem as tarefas a serem realizadas. Novamente, correu o risco de o cliente se negar a pagar e a GS ficar sem possibilidade de recorrer. Este fator está sendo recorrente na GS, o risco de ficar sem receber por trabalhos feitos, o que pode comprometer a rentabilidade da empresa.

Quadro 5 Avaliação do Processo pela visão da GSeabra comparada à do cliente

\begin{tabular}{|c|c|c|}
\hline Item & Visão da GS sobre o produto & Visão do Cliente sobre o produto \\
\hline $\begin{array}{l}\text { O Pedido do cliente é de fácil } \\
\text { execução? }\end{array}$ & $\begin{array}{l}\text { Não - Pois sem a visita prévia no } \\
\text { local ficaria vulnerável a novos } \\
\text { desafios }\end{array}$ & $\begin{array}{l}\text { Sim - Pois esperavam uma } \\
\text { simples conferência e aprovação da } \\
\text { GS. }\end{array}$ \\
\hline $\begin{array}{l}\text { A execução foi atendida no } \\
\text { prazo com facilidade? }\end{array}$ & $\begin{array}{l}\text { Sim - Pois todas as solicitações da } \\
\text { GS foram atendidas, tanto na } \\
\text { apresentação de documentos como } \\
\text { com o apoio dos profissionais da } \\
\text { fábrica }\end{array}$ & $\begin{array}{l}\text { Sim - Pois todas as solicitações da } \\
\text { GS foram atendidas, tanto na } \\
\text { apresentação de documentos como } \\
\text { com o apoio dos profissionais da } \\
\text { fábrica }\end{array}$ \\
\hline Conhece o risco envolvido? & $\begin{array}{l}\text { Sim - Pois pode causar uma } \\
\text { explosão e trazer riscos aos } \\
\text { funcionários e à instalação }\end{array}$ & $\begin{array}{l}\text { Sim - Pois pode causar } \\
\text { explosão e trazer riscos } \\
\text { funcionários e à instalação }\end{array}$ \\
\hline Conhece a norma? & Sim - Tem pleno conhecimento & $\begin{array}{l}\text { Não - Por conta disso houve a } \\
\text { contratação de um especialista em } \\
\text { combustível }\end{array}$ \\
\hline $\begin{array}{l}\text { Possui dados suficientes para } \\
\text { o início do trabalho? }\end{array}$ & $\begin{array}{l}\text { Sim - Pois os documentos foram } \\
\text { apresentados no dia em que o } \\
\text { sócio-fundador da GS foi realizar a } \\
\text { visita ao local }\end{array}$ & $\begin{array}{l}\text { Sim - Após uma condição imposta } \\
\text { pela GSeabra foi obrigado a reunir } \\
\text { todos os documentos solicitados }\end{array}$ \\
\hline $\begin{array}{l}\text { O material final entregue foi } \\
\text { de fácil entendimento? }\end{array}$ & $\begin{array}{l}\text { Sim- Estavam bem detalhados e } \\
\text { obedecendo à norma }\end{array}$ & $\begin{array}{l}\text { Sim - Pois com o material, os } \\
\text { engenheiros responsáveis pela } \\
\text { fábrica entenderam e liberou-se o } \\
\text { funcionamento do novo sistema } \\
\text { com Gás }\end{array}$ \\
\hline $\begin{array}{l}\text { A localização da fábrica é de } \\
\text { fácil acesso? }\end{array}$ & $\begin{array}{l}\text { Não - Devido à fábrica estar em } \\
\text { outro estado e ser necessário uma } \\
\text { locomoção demorada ao local }\end{array}$ & $\begin{array}{l}\text { Sim - Pois existem várias estradas } \\
\text { que levam ao local da instalação e } \\
\text { por morarem na região }\end{array}$ \\
\hline
\end{tabular}




\begin{tabular}{|c|c|c|}
\hline Existe risco à empresa? & $\begin{array}{l}\text { Sim - Pois caso os documentos } \\
\text { não fossem apresentados, o serviço } \\
\text { não seria feito e os gastos de } \\
\text { locomoção, hospedagem } \\
\text { alimentação não seriam } \\
\text { reembolsados }\end{array}$ & $\begin{array}{l}\text { Não- Pois se o serviço não fosse } \\
\text { feito pela GS, haveria outras } \\
\text { empresas para serem contatadas da } \\
\text { localidade, reconhecendo que seria } \\
\text { com menor qualidade. }\end{array}$ \\
\hline
\end{tabular}

Fonte: elaborado pelo autor

Neste $\mathrm{P}$ vemos que o processo foi bem detalhado pela GS e aceito pelo contratante, que disponibilizou os documentos requeridos e o pessoal solicitado para a realização da atividade, viabilizando o cumprimento da programação feita.

O projeto atendeu de forma eficiente ao objetivo final da contratação, pois com os dados levantados da GS, o cliente conseguiu realizar a substituição desejada sem problemas futuros.

Neste serviço não houve necessidade de trocas excessivas de e-mail e reuniões para esclarecimentos, o que otimizou o tempo dispendido pela GS, para as atividades.

Os únicos problemas vistos neste $\mathrm{P}$ foram o risco assumido voluntariamente pela GS, que poderia trazer prejuízos financeiros ao empreendimento base deste estudo, e a elaboração de um contrato somente após o início do projeto, aumentando os riscos financeiros, caso o cliente se recusasse a pagar.

Em contratações futuras, em que haja a hipótese da GS não aceitar a realização do trabalho, a depender da avaliação técnica das condições de execução do serviço, ela deve se resguardar e ter um documento formal para o ressarcimento dos custos de deslocamento ao cliente, quando o trabalho não for executado, especialmente quando envolver uma distância tão grande da sua sede.

\section{Análises e recomendações}

A partir das informações obtidas nas entrevistas com os colaboradores da GSeabra (GS) e na pesquisa de observação realizada, com base em e-mails, atas de reuniões, cronogramas, planos de ações, propostas e apresentações de slides para os clientes, foram elaboradas algumas recomendações para a GS aprimorar seu marketing de serviços, considerando-se a teoria dos 7P's: produto, preço, promoção, praça, pessoas, ambiente físico e processos. 
É importante ressaltar que dos 7p`s, o P relacionado a ambiente físico não foi avaliado, por se tratar de uma pesquisa de observação e em função da pandemia vigente, impossibilitando-se qualquer deslocamento, além de não ter havido necessidade de os clientes pesquisados irem até o escritório da GS.

$\mathrm{Na}$ análise dos P's a partir de e-mails, atas de reuniões, cronogramas, planos de ações, propostas e das apresentações criadas em slides aos clientes, foi verificado que praticamente quase todos os clientes entraram em contato com a GS por conta do networking e a referência do sócio-fundador.

Com base nas informações coletadas, identificamos que o empreendimento base deste estudo, apresenta pontos vulneráveis e deficientes em quase todos os P's, sendo os mais críticos, os P's relativos às pessoas e aos processos, que acabam impactando negativamente os P's de produto, preço, promoção e ambiente físico.

A partir dos dados coletados observa-se que o ponto forte do $\mathrm{P}$ de produto é qualidade do serviço prestado, contudo por se tratar de assuntos muito técnicos, nem sempre o cliente tem formação em engenharia para o entendimento geral. Recomenda-se que a GS utilize como ferramenta outros meios de exemplificação, tais como fluxogramas e relatórios fotográficos que possam facilitar o entendimento da solução apresentada. Isso facilitará a negociação do preço, pois muitas vezes os clientes acham que o serviço é mais simples do que o apresentado na proposta comercial.

Em relação a Preço, os colaboradores da GS consideram que está na média de mercado, pois é natural que os clientes queiram negociar um preço menor, muitas vezes por não ter o conhecimento específico do projeto a ser executado.

No que se refere a praça, a GS deve sempre avaliar melhor os custos logísticos em função da localização do cliente, em especial a dificuldade de acesso, sejam pela distância ou pelos horários do trânsito.

A respeito do $\mathrm{P}$ de promoção, foi observado que é básico para prover lucro à empresa, com a conquista de novos serviços. O melhoramento deste $\mathrm{P}$ é essencial, pois ao conquistar um número maior de clientes, a empresa base deste estudo poderá investir no aperfeiçoamento em pessoas e processos. Na entrevista com os colaboradores da GS, eles consideram que o desafio da GS é manter um fluxo de trabalho constante. A recomendação é que, além do networking que é muito utilizado pela GS, ela também identifique outras formas para buscar clientes que não fazem parte do seu ciclo de conhecimento. 
Os maiores desafios da GS em relação a pessoas, apontados pelo sócio-fundador e os seus colaboradores, relacionam-se a uma equipe técnica que tenha habilidades em vendas, manter um fluxo de trabalho constante, a falta de tempo para atender aos prazos reduzidos quando há aumento de volume de trabalho, fazendo com que a mesma não consiga atender às demandas em um curto prazo, possibilitando a transferência de serviços aos seus concorrentes. Já os pontos de melhoria seriam a criação de uma estratégia de marketing que explore mais as ferramentas disponibilizadas pela internet, para agilizar a divulgação através de um canal de comunicação e na estruturação de uma equipe de vendas para a diversificação dos produtos e atividades.

Os pontos mais críticos da GS em relação aos processos referem-se às falhas no planejamento das atividades dentro do cliente e na contratação de empresas terceirizadas, ausência ou formulação tardia do contrato que trazem riscos financeiros assumidos que podem comprometer um empreendimento do porte da GS e não aplicar treinamento aos colaboradores sobre o compartilhamento dos serviços com o cliente.

$\mathrm{Na}$ entrevista com o sócio-fundador, foi observado que o mesmo enxerga diversas necessidades de melhoria em quase todos os P's, porém ainda não sabe como agir na prática para melhorar a eficiência e eficácia do empreendimento base deste estudo, de forma contínua.

Os pontos listados anteriormente foram relevantes por conta de situações repetidas nos clientes, onde a GS cometia o mesmo equívoco. Estas falhas foram fundamentais para trazer complicações para os outros P's e, como consequência, para todo o restante do serviço. Também foi averiguado que a GS aprendeu com algumas más experiências, esforçando-se dentro do possível, por não deixar que se repetissem com clientes seguintes, trazendo benefícios para as atividades futuras.

Foi observado que a falta de planejamento ocorre quando os colaboradores da GS envolvidos em um projeto não estão completamente informados do que foi contratado, quando se baseiam em cronograma de terceiros para cumprimento do prazo de serviço programado, quando ficam esperando pelos documentos dos clientes sem estabelecer prazos, quando não dispõem de tempo para procurar no mercado outras opções de empresas, quando é necessária a contratação externa e faltam roteiros padronizados a serem adotados no início de cada serviço.

A ausência ou a formulação tardia do contrato é um fator negativo, pois a GS, no começo de suas atividades, não exigia a formulação deste documento. Porém, vendo o risco 
que poderia ocorrer, começou a utilizar contratos, mas, em função da urgência dos clientes e pela morosidade das empresas, o contrato acaba não sendo formalizado ou sendo entregue de forma tardia após o término das atividades. Sendo assim, o empreendimento fica exposto a não receber o valor total do serviço ou ter acréscimo de funções novas sem o aumento do valor da proposta acordada. Assim, caso ocorra algum entrave, não há documento que proteja a GS juridicamente.

Em consequência pela falta de um contrato, existe o risco financeiro somente pela parte da GS, podendo trazer para ela um prejuízo financeiro muito grande, por ser uma empresa de pequeno porte. A formulação de contratos reduziria estes riscos e, para prosperar, a empresa não pode ficar assumindo ameaças ao próprio caixa.

Vemos a necessidade da contratação de um assistente administrativo para ajudar a GS no escritório e assim prover uma maior organização dos documentos e das atividades. A função deste profissional seria coletar as informações que ocorreram nos serviços realizados, como problemas internos e externos, e realizar uma estruturação simplificada de quais foram os motivos destes impasses. Esta pessoa não iria participar das visitas de campo, seria responsável exclusivamente para obtenção de dados que melhorem o andamento das atividades. E assim, ajudando a GS a ter mais eficiência e eficácia nas atividades de que participará futuramente.

$\mathrm{Na}$ entrevista com o sócio-fundador da GS, ele mencionou que para poder contratar um assistente administrativo seria necessário que houvesse trabalhos contínuos com diversos clientes ou um contrato de longo prazo de um cliente, pois, assim, a GS poderia admitir um funcionário sem trazer riscos financeiros extras.

Visto ser essencial o aumento da demanda de serviços da GS, a recomendação seria a criação de um aplicativo que permita ser acessado por qualquer cliente fora do seu networking, possibilitando elaborar propostas comerciais de consultoria ou de projetos à distância, não sendo necessário o primeiro contato direto com a contratada. Os novos clientes fariam um cadastro no aplicativo, onde colocariam o seu CNPJ (Cadastro Nacional da Pessoa Jurídica), o nome do responsável, e-mail e telefone para iniciar o processo. Depois de incluídas estas informações, as organizações inseririam dados de suas instalações, o motivo da perícia ou da consultoria, o prazo final que desejariam, fotos do maquinário (optativa) e a necessidade de treinamento de funcionários. Após estes esclarecimentos seria gerado o valor do serviço e, caso a firma estivesse de acordo com o valor proposto, apareceriam para ela os documentos necessários para a visualização da GS. 
Por fim, a GS entraria em contato com a contratante para acertar o dia da visita, como iria atuar, se o prazo requerido pelo consumidor estaria de acordo com o tempo necessário para a realização da atividade, se necessitaria da utilização de funcionários da organização, se precisaria terceirizar outra empresa e seria aberta a negociação com o preço.

Além deste aplicativo, o empreendimento base deste estudo deveria criar contas nas redes sociais como Instagram e Facebook, a fim de aumentar ao máximo a sua capacitação de absorção de novos clientes. Estas formas de promoção contribuiriam para o acréscimo de contratantes e aumento de visibilidade no mercado.

Apesar das despesas para o desenvolvimento do aplicativo, a GS teria este valor reembolsado quando os clientes de diferentes segmentos entrassem em contato para realizar serviços, visto que para qualquer empreendimento melhorar seus pontos fracos é preciso utilizar valor monetário para fazer as mudanças necessárias e em um futuro próximo recuperar os gastos como um faturamento maior.

Com isto, a GS teria mais chances de reunir clientes potenciais que manteriam um fluxo constante de trabalho e assim poderia realizar a contratação de um assistente administrativo que organizasse o $\mathrm{P}$ de pessoas e processos. 


\section{Conclusão e Considerações Finais}

O presente trabalho foi elaborado com o propósito de analisar os 7 P's de marketing no empreendimento da GSeabra (GS). Para a realização deste estudo foi feita, primeiramente, uma entrevista com o gestor da empresa para investigar a viabilidade do estudo e conhecer melhor a sua forma de atuação. Em seguida, foi realizada uma pesquisa de cunho qualitativo através de entrevistas presenciais com o sócio-fundador e colaboradores e uma pesquisa de observação, através de e-mails, atas de reuniões, cronogramas, planos de ações, propostas e fotos. A partir desses dados foi possível chegar a algumas conclusões sobre as respectivas impressões dos colaboradores e dos clientes em relação à GS.

Entre os P's analisados, foi possível perceber que produto e praça estão bem estruturados e não afetam negativamente os resultados. $\mathrm{O}$ ambiente físico não é relevante para o negócio, pois em geral é a GS que vai até as instalações do cliente, onde ocorre o serviço. Os demais P's precisam ser melhor estruturados, pois impactam na organização e no faturamento da empresa.

No P de preço, foi constante a fragilidade encontrada nos diversos clientes analisados onde havia o risco de não ser remunerado ou de serem acrescidos novos serviços além do que foi relacionado em proposta, em função da falta de um contrato formalizado.

No $\mathrm{P}$ de pessoas, vimos a falta de uma equipe maior e mais bem treinada, já que cada colaborador realiza serviços diversos, precisando aprimorar os processos internos para atender à variedade de projetos solicitados pelo mercado e quando surgem novos serviços ao mesmo tempo, a GS não tem colaboradores disponíveis naquele momento para atender à demanda. Outro ponto que contribuiria seria ter outros colaboradores com a mesma experiência do sócio- fundador para aumentar sua disponibilidade na gestão do negócio.

Já no $\mathrm{P}$ de processos, observamos várias pontos a melhorar, como a contratação de terceiros com responsabilidade da GSeabra; colocação do prazo com base em um terceiro que não responde diretamente à empresa; má interpretação se o risco oferecido será compensador; ausência ou formulação do contrato de forma tardia, quando é firmado; planejamento precário e pouca padronização do passo a passo do que será feito; falha na integração dos profissionais internos dos clientes relacionados ao projeto; detalhamento insuficiente para iniciar o serviço nas instalações do cliente; iniciar os trabalhos sem a aceitação formalizada em contrato. 
Outro desafio é aumentar o leque de clientes potenciais. No momento, esta função está sendo realizada somente por networking do sócio-fundador, que, por possuir uma longa experiência no segmento em questão, obtém contatos com ex-colegas da sua antiga firma ou com profissionais com quem realizou trabalhos conjuntos. Dessa forma, se faz necessária a expansão da rede de clientes, bem como investir no marketing virtual e em softwares, ou seja, em formas que aumentem o contato de clientes fora do networking dos colaboradores e do sócio-fundador, assim como introduzir meios tecnológicos para ter esta expansão, como aplicativos e redes sociais, que contribuiriam para tornar os processos mais rápidos e assim captar novos clientes, como empresas fora do Rio de Janeiro, que se interessariam pelos serviços da GS.

Os pontos valorizados pelos clientes como diferenciais são a imparcialidade, atuação profissional, eficiência, conhecimento técnico e habilitação dos colaboradores no serviço.

Vale ressaltar o comprometimento da GSeabra com os prazos acordados com os clientes e a entrega de serviços com qualidade, além da explicação dos processos antes do fechamento da contratação. Além disso, o conhecimento e a dedicação dos colaboradores aliados à diversidade dos serviços apresentados também levam os clientes a se identificarem com a GSeabra e recomendá-la para a outras empresas.

Para pesquisas futuras, recomenda-se um estudo que busque investigar a ampliação da área de atuação de consultoria e perícia, novas padronizações de contatos que facilitem a relação com clientes e novas implementações de meios que favoreçam a melhoria do planejamento e a aplicação de contratos mais simples e rápidos, visto que as empresas buscam agilidade para resolver os seus problemas, pois algo mais trabalhoso traz desinteresse das firmas no processo.

Vale destacar a intenção da empresa base deste estudo na implementação de uma nova estratégia de marketing, focada na internet, levando em consideração a contratação de um assistente administrativo para auxiliar a GS com o melhoramento da eficácia e da eficiência nos P's de pessoas e processos. 


\section{$7 \quad$ Referências bibliográficas}

BEHERA, Medha. Os 7Ps do Marketing Mix. Elaborado pelo Ezine. Blueserenity, Brasil, março de 2020. Disponível em: https://www.blueserenity.pt/os-7ps-do-marketing-mix/. Acesso em: 11 maio, 2020.

CARDOSO, Filipa. Marketing de Serviços - 7 P's. Proddigital, Brasil, janeiro de 2016. Disponível em: https://proddigital.com.br/market/marketing-de-servicos-7-ps/. Acesso em: 11 out. 2019.

CASTILHOS, Roniara. Temer sanciona com 3 vetos projeto da Câmara sobre terceirização. G1, Brasil, março de 2017. Disponível em: https://g1.globo.com/politica/noticia/temer-sanciona-com-3-vetos-projeto-da-camara-sobreterceirizacao.ghtml. Acesso em: 10 out. 2019.

CONECT. Tudo que você precisa saber para implementar uma gestão eficaz de segurança do trabalho na sua empresa. Brasil, abril de 2018. Disponível em: https://conect.online/blog/tudo-que-voce-precisa-saber-para-implementar-uma-gestao-eficazde-seguranca-do-trabalho-na-sua-empresa/. Acesso em: 10 out. 2019.

DEBOÇÃ, L. et al. Estratégias mercadológicas e o composto de marketing: um estudo de caso em uma cooperativa agroindustrial no Paraná. Brasil, outubro de 2009. Disponível em: http://www.abepro.org.br/biblioteca/enegep2009_TN_STO_095_648_13102.pdf. Acesso em: 12 de junho de 2020.

ESCOLA NACIONAL DA INSPEÇÃO DO TRABALHO. (Org.). Normas Regulamentadoras - Português. Brasil, 2020. Disponível em: https://enit.trabalho.gov.br/portal/index.php/seguranca-e-saude-no-trabalho/sst-menu/sstnormatizacao/sst-nr-portugues?view=default. Acesso em: 06 jun. 2020.

FALCÃO, Marcelo. Os 7 P's do Marketing. Administradores, Brasil, outubro de 2005. Disponível em: https://administradores.com.br/artigos/os-7-ps-do-marketing. Acesso em: 04 out. 2019.

GRACIOSO, Francisco. Retrato do marketing de serviços no Brasil. Pág.26 até pág.31. Revista da ESPM, Brasil, setembro/outubro de 2013. Disponível em: http://ic.espm.br/Revista_ESPM_set_out_2013/files/assets/common/downloads/publication.p df. Acesso em: 05 out. 2019.

IBGE. Dados econômicos de empresas de serviços, 2017. Brasil, 2017. Disponível em: https://www.ibge.gov.br/estatisticas/economicas/servicos/9028-pesquisa-anual-deservicos.html?edicao=25270\&t=destaques. Acesso em: 05 out. 2019.

INSTITUTO BRASILEIRO DE COACHING. O que é marketing de serviço? Brasil, junho de 2016. Disponível em: https://www.ibccoaching.com.br/portal/o-que-e-marketing-deservico/. Acesso em: 05 out. 2019.

INTELLIPLAN. Consultoria de mercado - Como ela pode ajudar. Brasil, maio de 2016. Disponível em: https://www.intelliplan.com.br/consultoria-de-mercado-como-pode-ajudar. Acesso em: 07 out. 2019. 
JUNIOR, I. et al. Gestão da Qualidade e Processos. $12^{\circ}$ edição. Rio de Janeiro: Editora FGV,2012

KOTLER, P.; KELLER K. L. Administração de Marketing. 14º edição. São Paulo: Pearson, 2012.

MELO, Clara e Velasco L. Setor de serviços volta a crescer e ajuda na recuperação da economia. G1, Brasil, setembro de 2017. Disponível em: https://g1.globo.com/economia/noticia/setor-de-servicos-volta-a-crescer-e-ajuda-narecuperacao-da-economia.ghtml. Acesso em: 10 out. 2019.

MIGRE SEU NEGÓCIO. Mix de Marketing - Os que são os 7Ps e os 4Cs do novo marketing. Brasil, dezembro de 2017. Disponível em: https://migreseunegocio.com.br/mixde-marketing/. Acesso em: 11 out. 2019.

NETO, Nestor. O que é NR. Segurança do Trabalho NWN, Brasil, junho de 2012. Disponível em: https://segurancadotrabalhonwn.com/o-que-e-nr/. Acesso em: 10 out. 2019.

PEREIRA, P. T. V. Qual a importância de um especialista em consultoria empresarial?

SEBRAE, Brasil, abril de 2020. Disponível em: https://blog.sebrae-sc.com.br/importancia-daconsultoria-empresarial/. Acesso em: 10 de junho de 2020.

PONTES, Marcelo Chiavone et al. Marketing de serviços: 12 anos depois, melhorou. Pág. 35 até pág.41. Revista da ESPM, Brasil, setembro/outubro de 2013. Disponível em:http://ic.espm.br/Revista_ESPM_set_out_2013/files/assets/common/downloads/publicatio n.pdf. Acesso em: 05 out. 2019.

PORTAL EDUCAÇÃO. Marketing de Serviços. Brasil, fevereiro de 2013. Disponível em: https://www.portaleducacao.com.br/conteudo/artigos/administracao/marketing-deservicos/34607. Acesso em: 05 out. 2019

POSSETTI, Douglas Alex. Conceitos e Aplicações do Marketing de Serviços. Administradores, Brasil, junho de 2010. Disponível em: https://administradores.com.br/producao-academica/conceitos-e-aplicacoes-do-marketing-deservicos. Acesso em: 05 out. 2019.

ROMAnO, Luiz Affonso. Como está o Mercado da Consultoria. Laboratório da Consultoria, Brasil, abril de 2019. Disponível em: https://laboratoriodaconsultoria.com.br/como-esta-o-mercado-da-consultoria/. Acesso em: 07 out. 2019.

SANTOS, Bruno F. CONSULTORIA E GESTÃO EMPRESARIAL: CONHEÇA ESSE MERCADO. ConsultingNow, Brasil, junho de $2018 . \quad$ Disponível em: https://www.consultingnow.com.br/consultoria-e-gestao-empresarial-conheca-esse-mercado/. Acesso em: 07 out. 2019.

SANTOS, Eder. 10 multas que a empresa pode ter que pagar ao não cumprir as obrigações de SST. SST, Brasil, novembro de 2018. Disponível em: http://www.sstonline.com.br/10-multas-que-a-empresa-pode-ter-que-pagar-ao-nao-cumpriras-obrigacoes-de-sst/. Acesso em: 04 out. 2019. 
SEBRAE. Marketing de serviços: uma visão baseada nos 8 Ps. Brasil, fevereiro de 2015. Disponível em: https://www.sebrae.com.br/sites/PortalSebrae/artigos/marketing-de-servicosuma-visao-baseada-nos-8-ps,a799a442d2e5a410VgnVCM1000003b74010aRCRD. Acesso em: 03 out. 2019

SIBROM. A Consultoria empresarial e o cenário atual. Estadão, Brasil, março de 2017. Disponível em: https://economia.estadao.com.br/noticias/releases-ae,a-consultoriaempresarial-e-o-cenario-atual,70001689964. Acesso em: 07 out. 2019. 


\section{Anexo I}

\section{QUESTIONÁRIO PARA OS COLABORADORES}

1) Qual sua idade?

2) Qual sua formação?

3) Quais foram os lugares em que você já trabalhou?

4) Como chegou à GSeabra?

5) Qual foi sua primeira percepção quando entrou na empresa?

6) O que você viu como diferencial para fazer parte da equipe da GSeabra?

7) Em qual oportunidade, na sua percepção, a empresa não investe?

8) Qual o risco que a GSeabra parece não perceber?

9) Como você vê a empresa no mercado?

10) Qual sua opinião referente aos concorrentes?

11) Quais os fatores que fazem a GSeabra ser única, se comparada aos concorrentes?

12) Qual o diferencial da empresa?

13) Qual o maior dasafio da GSeabra?

14) Qual a sua percepção sobre os clientes da empresa?

15) O que faz os consumidores procurarem a GSeabra? Por que os clientes procuram a empresa?

16) De acordo com a sua opinião, quais os maiores desafios enfrentados pela empresa?

17) Qual sua visão sobre o futuro da empresa? O que você espera da empresa no futuro?

18) Para você, quais os pontos fortes e fracos da GSeabra?

19) Qual o objetivo da empresa atualmente?

20) O que você sugeririra para tornar a empresa mais eficiente?E eficaz?

21) O que você acha que a empresa pode melhorar? E como?

22) Você acha que a empresa está realizando uma boa estratégia de marketing? Se sim, como é ? Se não, como você acha que deveria ser?

23) Você acredita que o preço apresentado pela GSeabra está de acordo com o mercado, ou seja, com os concorrentes? Se não, o preço está elevado ou abaixo?

24) Você acredita que a empresa está bem localizada? Ela está em um ambiente que o público-alvo está concentrado? 
25) Os produtos oferecidos pela GSeabra distinguem-se dos apresentados pelos concorrentes? Por quê?

26) Os treinamentos usados são eficientes ou precisam sofrer mudanças para serem mais eficientes?

27) O ambiente de trabalho no dia a dia é bom?

28) O processo da realização de um serviço é bem exemplificado pelo sócio-fundador? Você tem fácil acesso a esse processo, caso tenha dúvidas de como realizar um serviço?

29) Você acha que o processo é eficiente ou possui etapas que podem ser eliminadas ou adicionadas?

30) Qual a frequência de elogio do serviço? E crítica?

31) Você sente que o cliente fica incomodado com alguma parte do serviço?

32) Qual a parte do serviço que o cliente mais critica? E qual mais elogia?

33) Você sente liberdade para demonstrar suas ideias? Alguma ideia que você já deu foi implementada?

34) Como você vê a empresa daqui há 5 anos?

35) Você julga as ações de marketing da empresa eficientes?

36) Qual ação nova de marketing você acreditaria ser eficiente para a empresa?

37) Se você estivesse como dono da empresa, qual seria sua primeira ação visando ao melhoramento da GSeabra?

38) Você tem alguma questão que julgue importante e que não foi abordada neste questionário? 


\section{Anexo II}

\section{QUESTIONÁRIO PARA A BASE DA OBSERVAÇÃO DOS CLIENTES}

\section{Produto:}

1) Reação dos clientes quando os serviços oferecidos são apresentados.

2) Os clientes indagam a forma da empresa trabalhar ou eles simplesmente aceitam?

3) Os clientes perguntam e mostram-se interessados em todos os projetos antigos da GSeabra?

4) Os clientes aceitam facilmente as novas demandas de serviço ou acham que estão sendo enganados?

5) Os clientes, depois de descobrirem outros problemas, continuam com a GSeabra ou procuram outras empresas?

6) Os clientes parecem satisfeitos com o que é oferecido?

7) Os clientes ficam impacientes com os colaboradores, quando os mesmos procuram oferecer outros serviços para a contratante?

8) Existem outros produtos que as empresas concorrentes oferecem e a GSeabra não?

9) Os clientes apresentam soluções diferentes das que foram dadas pela GSeabra?

10) De acordo com os clientes, a GSeabra busca por mais informações sobre o problema do serviço do que as outras empresas? Apresenta certa precaução a mais sobre os serviços que serão feitos do que os concorrentes?

\section{Preço:}

1) Os clientes sempre comparam o preço da GSeabra com os das outras empresas, a fim de tentar diminuir o valor?

2) Os clientes sempre tentam pechinchar?

3) Quais os comentários dos clientes sobre o preço do mercado? Positivos ou negativos?

4) Os clientes falam que as outras empresas usam outros métodos para fazer o preço?

5) Os clientes aceitam a proposta no ato ou falam que terão que pensar sobre o preço apresentado?

6) Os clientes concordam que o preço está em linha com os dos concorrentes?

7) A GSeabra realiza descontos para não perder o cliente, mesmo ficando no prejuízo?

8) Ocorre uma pesquisa de mercado pelos colaboradores para afirmar que os preços da GSeabra estão um pouco mais altos que os dos concorrentes?

9) Os concorrentes realizam descontos? Se sim, como funcionam esses descontos?

10) A GSeabra aplica descontos com frequência ou apenas em determinadas situações? 


\section{Promoção:}

1) Os clientes que entram em contato são conhecidos, seja por trabalhos antigos ou colegas que já realizaram serviço com a GSeabra, ou são pessoas de outros meios?

2) Os colaboradores apresentam para os clientes formas de encontrar a GSeabra em sites ou em alguma plataforma?

3) Os colaboradores perguntam sugestões para os clientes de como melhorar a promoção?

4) Os clientes cobram um site melhor, já que é a única forma de fazer contato aleatoriamente e de fazer a divulgação?

5) O contato dos clientes com a empresa é pelo celular privado de cada colaborador ou da empresa, mostrando profissionalismo?

6) Como é a promoção das concorrentes da GSeabra?

7) Os clientes falam da falta de divulgação da GSeabra, tanto na internet como em outros meios?

8) Os clientes comparam a divulgação da GSeabra com os seus concorrentes?

9) A GSeabra entrega cartões de visita para os clientes que querem realizar serviço ou realizaram alguma atividade para serem distribuídos para colegas de trabalho, amigos ou deixá-los no escritório para os clientes deles terem acesso?

10) Reparar se a divulgação dos clientes para amigos ou colegas é realmente eficiente para gerar um determinado lucro ou se é valido pensar em outras formas de realizar a divulgação.

\section{Praça:}

1) Quando o cliente chega ao local, ele reclama de falta de estacionamento? Longe do metrô?

2) Anotar quando o cliente fala de onde é.

3) Por conversa informal com o dono ou colaboradores, perceber se ele fez o caminho contrário para estar lá ou se desmarcou por algum motivo de localidade.

4) Os colaboradores observam outras formas de entrar em contato com os clientes sem ser físico?

5) Visão dos compradores quando eles falam sobre o site da GSeabra (opiniões).

6) Os clientes falam de outras formas que facilitariam o contato com a GSeabra?

7) As concorrentes possuem mídias sociais mais expressiva, como páginas no Facebook ou Instagram?

8) Os concorrentes possuem mais formas de contatos na internet que a GSeabra?

9) Os clientes dão dicas para a GSeabra sobre formas de aprimorar a forma de entrar em contato?

10) O cliente tem o costume de realizar comparações da GSeabra com os concorrentes, quando o assunto é a facilidade de entrar em contato? 


\section{Pessoas:}

1) Os colaboradores conseguem explicar o problema com termos simples?

2) Os colaboradores conseguem mostrar convicção do que estão falando?

3) Os colaboradores conseguem convencer os clientes mais difíceis?

4) Ocorre uma falta de entendimento do cliente após a explicação do colaborador?

5) Quando o cliente realiza uma pergunta, a resposta dos colaboradores é rápida?

6) Os colaboradores são assertivos e diretos nas respostas aos clientes?

7) O cliente indaga que um colaborador disse algo e outro colaborador se pronunciou diferente sobre o mesmo assunto?

8) Como os colaboradores são treinados? É suficiente?

9) Para o objetivo da empresa, os colaboradores estão com o treinamento correto?

10) Existem treinamentos online gratuitos ou com preços acessíveis que entram na diretriz do que a GSeabra espera que eles realizem, como treinamentos online para o melhoramento das vendas?

\section{Ambiente Físico:}

1) Observar a reação das pessoas assim que entram no escritório. Se elas dão uma olhada geral ou focam em algo.

2) Sentir se elas ficam incomodadas com a circulação de pessoal pelo estabelecimento durante as reuniões.

3) Perceber se eles estão à vontade no escritório e se eles se incomodam que a GSeabra vá até eles (gasto de Transporte desnecessário da GSeabra).

4) Os clientes depreciam o ambiente em que se encontra o escritório da GSeabra?

5) Quando estão na reunião, eles se mexem muito? (Pois mostra um certo desconforto sobre o ambiente).

6) Os olhares dos clientes estão fixos na proposta apresentada pela GSeabra ou eles dão olhadas gerais no ambiente?

7) Elas costumam ir muito no banheiro durante as reuniões? (Mostra impaciência com o ambiente em questão)

8) Observar a organização do escritório.

9) Observar a quantidade de pessoas que passam no escritório durante o dia e ver se é confortável para o espaço em questão.

10) Depois de apresentada a proposta no escritório, os clientes sugerem que o resto da conversa seja em outro lugar, como um restaurante? 


\section{Processos:}

1) De acordo com as atas de reuniões, observar se os temas colocados em questão estão sendo obedecidos e no prazo determinado.

2) De acordo com os e-mails, verificar se os clientes estão realizando muitas indagações.

3) De acordo com os e-mails, verificar se os clientes estão realizando muitas reclamações e se estão criticando a demora das respostas.

4) Reparar como começam os contatos, se é por e-mail ou por telefone.

5) Os clientes indagam que o tempo para um serviço está muito longo?

6) O cliente tem muitas dúvidas durante o processo?

7) Ocorrem muitas indagações dos clientes?

8) É normal que os clientes busquem outros concorrentes, na procura de serviços mais rápidos?

9) A participação dos clientes nas etapas é algo satisfatório para a GSeabra ou só querem o resultado final? 